\title{
Chromium isotope stratigraphy of Ediacaran cap dolostones, Doushantuo Formation, South China
}

\author{
Rodler A.S. ${ }^{\mathrm{a}, \mathrm{b}, *}$, Hohl S.V. ${ }^{\mathrm{c}}$, Guo Q. ${ }^{\mathrm{d}}$, Frei R. ${ }^{\mathrm{a}, \mathrm{b}}$ \\ a Department of Geosciences and Natural Resource Management, University of Copenhagen, Øster Voldgade 10, 1350 Copenhagen, Denmark \\ ${ }^{\mathrm{b}}$ Nordic Center for Earth Evolution (NordCEE), Denmark \\ c Institute for Geoscience, Department for Geochemistry, Freie Universität Berlin, Malteserstr. 74-100, 12249 Berlin, Germany \\ d Center for Environmental Remediation, Institute of Geographic Sciences and Natural Resources Research, Chinese Academy of Sciences, Beijing 100101, China
}

\section{A R T I C L E I N F O}

\section{Article history:}

Received 8 September 2015

Received in revised form 30 April 2016

Accepted 3 May 2016

Available online 7 May 2016

\section{Keywords:}

Yangtze Platform

Detrital contamination

Al-corrected $\mathrm{Cr}$ signals

Diagenetic alteration

Coeval oxygenated seawater $\mathrm{Cr}$ composition

\begin{abstract}
A B S T R A C T
The Yangtze Platform in South China is considered a key site for studying Neoproterozoic ocean oxygenation Comprehensive $\mathrm{Cr}$ concentration and isotopic signatures are presented from cap dolostones of the Doushantuo Formation from a deep water and a shallow marine carbonate section, that have previously been used to constrain the redox evolution of Ediacaran seawater in space and time employing major and trace element abundances as well as Sr-, O- and C-isotope compositions. The majority of the studied samples yield elevated $\mathrm{Cr}$ concentrations and negatively fractionated $\delta^{53} \mathrm{Cr}$ signals due to (i) detrital contamination consistent with $\mathrm{Cr}$ signatures of other post-Marinoan cap dolostones, (ii) diagenetic carbonate alteration and post-depositional remobilization of $\mathrm{Cr}$. Al concentrations were used as indicator of detrital contamination and to calculate authigenic $\mathrm{Cr}$ concentration and isotope signatures when the detrital contribution of $\mathrm{Cr}$ was $<40 \%$, which generally resulted in slightly lower $\mathrm{Cr}$ concentrations and slightly higher $\mathrm{Cr}$ isotopic signals in these samples. Diagenetic alteration of a majority of the studied cap dolostones is evident from low $\mathrm{Sr}$ concentrations and light $\delta^{18} \mathrm{O}_{\text {carb }}$ signals that correlate with low $\mathrm{Cr}$ concentrations and negatively fractionated $\delta^{53} \mathrm{Cr}$ values. Post-depositional remobilization of $\mathrm{Cr}$ results in the loss of heavy $\mathrm{Cr}$ isotopes and consequently light $\mathrm{Cr}$ isotopes are retained during precipitation of secondary carbonates. However, some samples might still show pristine Ediacaran seawater signals. Two samples pertaining to the deep water cap dolostone section at Yanwutan and one sample pertaining to the shallow water section at Jijiawan yield slightly positively fractionated $\delta^{53} \mathrm{Cr}$ signals, particularly when corrected to presumably authigenic signals $\left(\delta^{53} \mathrm{Cr}_{\text {auth }}\right)$. These values are consistent with those from other Neoproterozoic carbonate sections deposited in an oxygenated environment. This short sequence of positively fractionated $\delta$ ${ }^{53} \mathrm{Cr}_{\text {auth }}$ is concurrent with a cap dolostone ${ }^{87} \mathrm{Sr} /{ }^{86} \mathrm{Sr}$ signal close to Ediacaran seawater values with relatively high $\mathrm{Sr}$ and $\mathrm{Cr}$ concentrations, with decreased detrital contamination and with a pronounced negative $\mathrm{Ce}$ anomaly. They indicate either light pulses of enhanced oxidative weathering or, inferred from a few leastaltered samples, prevailing oxic conditions during cap dolostone deposition. The $\mathrm{Cr}$ isotopic composition of Ediacaran cap dolostones pertaining to the Doushantuo Formation reveals fine-scale fluctuations in postglacial detrital contamination and diagenesis balanced against a clear signal of oxidative weathering. $\mathrm{Cr}$ isotopes have the potential to further enhance our understanding of Neoproterozoic weathering regimes and past ocean oxygenation, however, before the $\mathrm{Cr}$ isotope system can be faithfully applied to delineate changes in redox conditions recorded in ancient marine carbonates, possible diagenetic alteration of the $\mathrm{Cr}$ signal as well as $\mathrm{Cr}$ contribution from detrital contamination need to be taken into consideration.
\end{abstract}

(c) 2016 Elsevier B.V. All rights reserved.

\section{Introduction}

The Neoproterozoic shows the most significant increase in atmospheric $\mathrm{O}_{2}$ concentration in Earth's history (Holland, 2006) accompanied by significant changes in ocean redox conditions from anoxic (maybe ferruginous) to oxic conditions in the deep and shallow seawater (Canfield et al., 2008; Johnston et al., 2010; Li et al., 2010); various models

\footnotetext{
* Corresponding author at: Øster Voldgade 10, DK-1350 Copenhagen, Denmark

E-mail address: alexandra.rodler@reflex.at (A.S. Rodler).
}

have been proposed to understand the climate evolution during the Neoproterozoic (Fairchild and Kennedy, 2007). However, remarkable environmental changes characteristic for the Neoproterozoic eventually facilitated the development of complex, aerobic life (e.g. Zhu et al., 2007; Knoll, 2011; Sahoo et al., 2012).

The progression of oxidative continental weathering and redox conditions in the marine realm throughout Earth's past can be inferred from concentrations and isotope signatures of redox sensitive trace elements recorded in chemically precipitated sediments (e.g. Anbar et al., 2007; Asael et al., 2013; Bekker et al., 2004; Rouxel et al., 2005). Ancient marine 
sediments potentially yield information about the chromium $(\mathrm{Cr})$ isotopic variation of seawater in the geological past, which possibly allow to infer the oxygenation history of the oceans and atmosphere (e.g. Frei et al., 2009; Crowe et al., 2013; Planavsky et al., 2014). Cr has a relatively simple speciation chemistry (Ellis et al., 2002). Of the environmentally stable $\mathrm{Cr}(\mathrm{III})-\mathrm{Cr}(\mathrm{VI})$ redox pair, $\mathrm{Cr}(\mathrm{VI})$ is highly soluble whereas $\mathrm{Cr}(\mathrm{III})$ is highly particle-reactive and forms insoluble $\mathrm{Cr}$ hydroxide complexes (Rai et al., 1987). The oxidation of $\mathrm{Cr}$ (III) to $\mathrm{Cr}(\mathrm{VI})$, catalyzed by Mn-oxyhydroxides (Eary and Rai, 1987; Fendorf and Zasoski, 1992), is accompanied by an isotopic fractionation where the mobilized $\mathrm{Cr}(\mathrm{VI})$ is enriched in the heavier isotope ${ }^{53} \mathrm{Cr}$ (Ellis et al., 2004, 2002; Zink et al., 2010) while no significant isotope effect was observed during adsorption of $\mathrm{Cr}(\mathrm{VI})$ onto particles (Ellis et al., 2004). This means, that the weathered soil remains isotopically lighter in respect to $\mathrm{Cr}$ while oxidative atmospheric weathering enriches the run-off in ${ }^{53} \mathrm{Cr}$ ( Izbicki et al., 2008; Crowe et al., 2013; Frei and Polat, 2013; Berger and Frei, 2014). The isotopically heavy, mobilized $\mathrm{Cr}(\mathrm{VI})$ is then transported by rivers (Farkaš et al., 2013; Frei et al., 2014; Paulukat et al., 2015) possibly affected by signals derived from regional variable $\mathrm{Cr}$ isotopic compositions of geologically different drainage systems (Scheiderich et al., 2015) - to the open ocean, where oxygenated water bodies stabilize it. This is perhaps indicated by a comparison of the surface seawater $\delta^{53} \mathrm{Cr}$ signature of the Argentinian Basin (Bonnand et al., 2013), and water samples of the Paraná River estuary and of the Paraná river (Frei et al., 2014). Results of these studies allow postulating that isotope effects during riverine transport of $\mathrm{Cr}$ to the oceans are not significant, and that the point sources of $\mathrm{Cr}$ have a dominant effect on the local $\mathrm{Cr}$ isotope signal recorded in seawater. This is consistent with findings for another locality recently reported by Paulukat et al. (2015). Ocean $\mathrm{Cr}$ isotope signals were also found to correlate strongly with $\mathrm{Cr}$ concentration (Scheiderich et al., 2015) and Cr incorporation into synthetic calcite indicated marginal to no effects on $\mathrm{Cr}$ isotope fractionation between ambient seawater and marine abiogenic carbonates (Dixon et al., 2013; Rodler et al., 2015). However, a possibly more complex internal redox cycling of $\mathrm{Cr}$ in the ocean can be assumed based on the variability of $\mathrm{Cr}$ isotope signatures in river water (Farkaš et al., 2013; Frei et al., 2014; Paulukat et al., 2015) and the heterogeneity of $\delta^{53} \mathrm{Cr}$ in modern ocean seemingly dependent on water depth, water-mass sources and mixing of water masses (Scheiderich et al., 2015).

Here, we investigate the $\mathrm{Cr}$ isotope signature of a deep water and a shallow marine cap dolostone section pertaining to the Doushantuo Formation (635-551 Ma; Condon et al., 2005) on the Yangtze Platform, and their use as redox archives of ancient seawater conditions. The Doushantuo Formation is considered one of the key formations for studying ocean oxidation and animal evolution in the aftermath of the Marinoan glaciation. We investigate the $\mathrm{Cr}$ isotope stratigraphy in the context of a previous study that included cap dolostones from the Doushantuo Formation to delineate paleo-redox conditions from detailed isotope, major and trace element variations (Hohl et al., 2015).

\section{Geological setting}

The Yangtze Platform in South China is certainly one of the best geological archives for studying the Ediacaran Ocean. It was established on the SE flank of the Yangtze Block continental margin creating a continuous marine sedimentary record of shallow- and deep water facies (e.g. Jiang et al., 2011). In the last two decades, the Doushantuo Formation on the Yangtze Platform became the most promising spot for studying temporal and lateral ocean oxygenation and nutrient influx in the Neoproterozoic as marine sediments cover the critical time span following the low latitude Marinoan glaciation. $\mathrm{U} / \mathrm{Pb}$ geochronology in various ash beds throughout the Doushantuo Formation have been used to infer the age of $635.2 \pm 0.6 \mathrm{Ma}$ at the beginning of the cap dolostone deposition to $551.1 \pm 0.7$ Ma shortly before the Precambrian/ Cambrian boundary spanning almost $90 \%$ of the Ediacaran (Condon et al., 2005) and covering the emergence of early animal life (Xiao et al., 1998; Zhu et al., 2007).

The cap dolostones building up the lower part of the Doushantuo Formation overlie tillites of the Nantuo Formation and are predominantly composed of massive dolostones with unusual light $\delta^{13} \mathrm{C}_{\mathrm{carb}}$ isotope anomalies and unique sedimentological structures such as tepees, rip up clasts, veins and crossbedding, presumably as a result of deposition during the change from icehouse to greenhouse conditions (Font et al., 2010).

The Yanwutan section (YAW) is situated E of the city of Jishou, Hunan province (N28 $25^{\prime} 20.0^{\prime \prime}$ E110 $28^{\prime} 42.1^{\prime \prime}$; Fig. 1). The cap dolostones and overlying mudstones of the lower Doushantuo at Yanwutan were deposited in deep waters of the Nantuo Basin (Guo et al., 2007; Zhu et al., 2007; Ader et al., 2009) whereas the middle and upper Doushantuo are considered to be composed of a massive slide sheet from a more shallow water environment (Vernhet et al., 2006). However, Guo et al. (2007) and Hohl et al. (2015) have shown that negative $\delta^{13} \mathrm{C}_{\text {carb }}$ values and trace element enrichments occur throughout the Yanwutan section, which therefore correlate with other deep water sections throughout the platform (Jiang et al., 2007; Ader et al., 2009).

The Jijiawan section (JJW), Hubei province (N30 ${ }^{\circ} 52^{\prime} 59.9^{\prime \prime} \mathrm{E} 110^{\circ} 52^{\prime}$ 45.4"; Fig. 1) is located on the southern flank of the Yangtze River, $17 \mathrm{~km}$ west of Maoping (Zhu et al., 2007). It is described to have been deposited under shallow marine conditions in a large intra shelf basin, separated by over $100 \mathrm{~km}$ from the south-facing slope of the Yangtze Platform (Vernhet, 2007). The basal part of cap dolostones of the JJW section consists of brecciated dolostones with several calcitic veins. The middle part contains fine-laminated micritic dolostones and chert layers. The top of the cap dolostone member is a massive dolomite with slump-fold structures (Hohl et al., under review). The cap dolostones are overlain by a black shale horizon with an ash layer that has been precisely dated by Condon et al. (2005) to $632.5 \pm 0.5 \mathrm{Ma}$ using $\mathrm{U}-\mathrm{Pb}$ chronology.

\section{Analytical procedures}

\subsection{Sample preparation, elemental and $\mathrm{C}, \mathrm{O}$ and $\mathrm{Sr}$ isotope analyses}

We used rock powders of 5 cap dolomite rocks pertaining to the Doushantuo Formation at the Yanwutan section, which have been described in detail by Guo et al. (2007) and Hohl et al. (2015) and rock chips of 7 cap dolostones pertaining to the Doushantuo Formation at the Jijiawan section that were crushed and subsequently milled in an automatic agate mortar (Fritsch pulverisette, type 02.102) to prepare rock powders. The cap dolostones pertaining to the Jijiawan section are described in detail by Hohl et al. (under review). Only ultrapure acids (double distilled or Seastar ${ }^{\mathrm{TM}}$ ) and ultrapure water from a MilliRho-Milli-Q system (18 M $\Omega$ MilliQ ${ }^{\mathrm{TM}}$ ) were used to treat the samples, which were processed and stored using previously cleaned Teflon ${ }^{\mathrm{TM}}$ beakers (cleaned with $6 \mathrm{~mol} \mathrm{~L}^{-1} \mathrm{HCl}$ at $130^{\circ} \mathrm{C}$ for $24 \mathrm{~h}$ ). Sample preparation and ion chromatographic separation were all performed in Class 1000 clean rooms. Sample leachates were prepared by dissolving $\sim 20 \mathrm{mg}$ rock powder in $2 \mathrm{~mol} \mathrm{~L}^{-1} \mathrm{HCl}$ for $\sim 10 \mathrm{~min}$. Elemental concentrations of these sample leachates were determined by inductively coupled plasma-optical emission spectrometry (ICP-OES; Perkin Elmer, Optima 7000 DV) and calibrated against a series of synthetic solutions prepared from certified single element solutions (Perkin Elmer). The external reproducibility was assessed by multiple analyses of the international reference materials JDo-1 (Permian dolostone, $n=22$ ) and JLs-1 (Triassic limestone, $n=3$ ), which were within the range of the certified values (Imai et al., 1996); the results for $\mathrm{Al}$ and $\mathrm{Sr}$ concentrations ( $\mu \mathrm{g} \mathrm{g}^{-1}$ ) show a relative standard deviation (1RSD) of $<5 \%$.

Major and trace element concentrations of the cap dolostone samples were analyzed in acetic acid leachates as outlined by Hohl et al. (2015). In 
a)

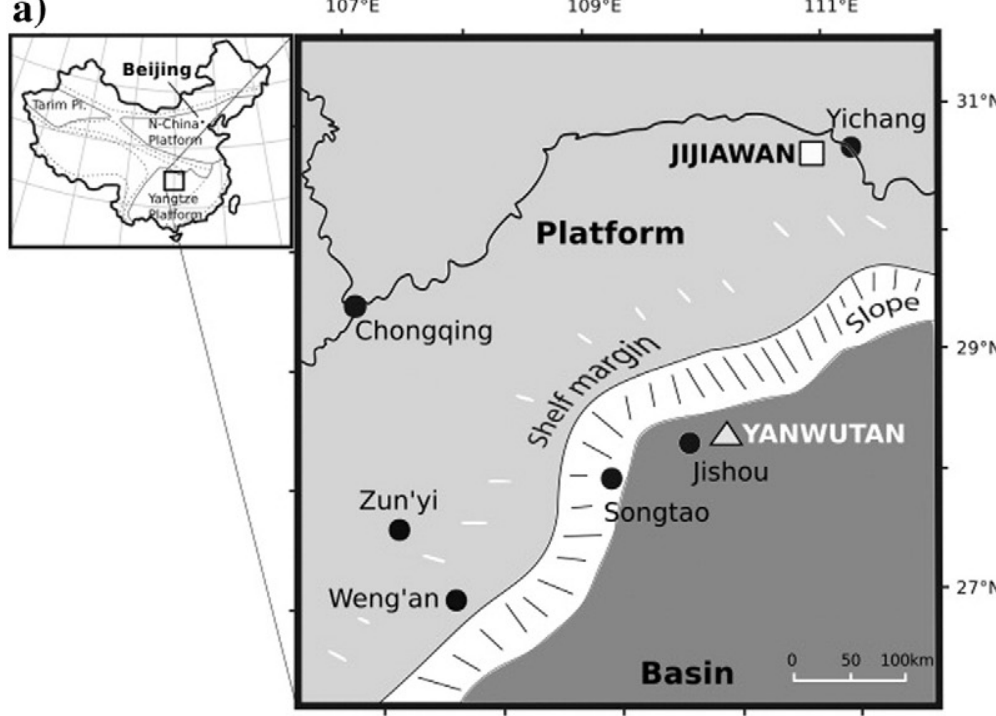

b)

$31^{\circ} \mathrm{N}$

YAW $505 \triangle$

YAW $504 \triangle$

YAW $503 \triangle$
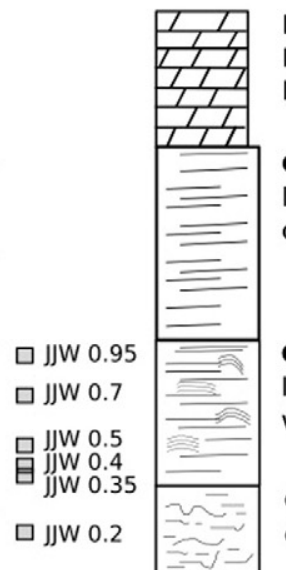

Doushantuo

lime and dolostones

C3

laminated micritic

dolomite

\section{C2}

laminated dolostones

with teppe structures

C1

disrupted dolomicrite

YAW $500 \Delta$ 口JJW 0.0

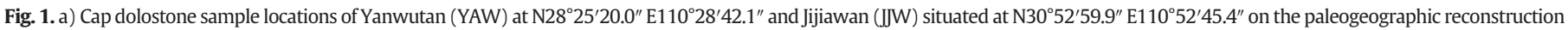
of the Yangtze Platform margin 635 Ma ago; b) schematic stratigraphic column of the cap carbonates deposited on the Yangtze Platform and the relative positions of samples within. Panel a is modified after Jiang et al. (2011); panel b is modified after Jiang et al. (2003).

short, $20 \mathrm{mg}$ sample powder were treated with $3 \mathrm{~mol} \mathrm{~L}^{-1}$ acetic acid for $12 \mathrm{~h}$ at $70^{\circ} \mathrm{C}$ to dissolve all carbonate phases, which was confirmed by XRD analyses. The samples were then centrifuged, filtrated $(0.45 \mu \mathrm{m}$ cellulose acetate syringe filters), dried to remove remaining acetic acid and redissolved in $3 \mathrm{~mol} \mathrm{~L}^{-1} \mathrm{HNO}_{3}$ for subsequent major and trace element analyses that were performed on a Thermo-Finnigan Element XR sector-field ICP mass spectrometer (ICP-MS) at Freie Universität Berlin, Germany. We use results of the dolomite fraction (wt.\%), Ti concentrations, $\mathrm{Mn} / \mathrm{Sr}$ ratios, total rare earth element concentrations ( LREE), Y/Ho ratios, Ce and Eu anomalies (Table 3) reported by Hohl et al. (2015) and Hohl et al. (under review). Values for Ce and Eu anomalies were shale-normalized (sN) to PAAS (Post-Archean Australian Shale; Taylor and McLennan, 1985; McLennan, 1989) and calculated following Lawrence and Kamber (2006), $\left(\mathrm{Ce} / \mathrm{Ce}^{*}\right)_{\mathrm{SN}}=\mathrm{Ce}_{\mathrm{SN}} /\left(\mathrm{Pr}_{\mathrm{SN}} * \mathrm{Pr}_{\mathrm{SN}} / \mathrm{Nd}_{\mathrm{SN}}\right)$ and $\left(\mathrm{Eu} / \mathrm{Eu}^{*}\right)_{\mathrm{SN}}=\mathrm{Eu}_{\mathrm{SN}} /\left(\mathrm{Sm}_{\mathrm{SN}}^{2} * \mathrm{~Tb}_{\mathrm{SN}}\right)^{1 / 3}$, in order to avoid calculating apparent depletions due to naturally enriched La and Gd concentrations (Ling et al., 2013; Hohl et al., 2015).

Aliquots of samples dissolved for major and trace elemental concentrations as described earlier and by Hohl et al. (2015) were used to analyze ${ }^{87} \mathrm{Sr} /{ }^{86} \mathrm{Sr}$ ratios by a Thermo-Finnigan Triton TIMS at Freie Universität Berlin, Germany, and are reported by Hohl et al. (2015) and Hohl et al. (under review). Carbonate carbon and oxygen isotopic compositions of samples pertaining to the JJW section were analyzed at Freie Universität Berlin, Germany, and are reported in detail by Hohl et al. (under review). Total organic carbon (TOC, wt.\%), carbonate carbon and oxygen isotopic compositions of samples pertaining to the YAW section (Table 3) were analyzed using a Finnigan MAT 252 mass spectrometer at the Institute of Geochemistry, Chinese Academy of Sciences, Guiyang, China, and are reported in detail by Guo et al. (2007). All carbonate carbon and oxygen isotopic compositions are reported as $\delta^{13} \mathrm{C}_{\text {carb }}$ and $\delta^{18} \mathrm{O}_{\text {carb }}(\%)$ relative to the Vienna Peedee Belemnite Standard (VPDB).

\subsection{Stable Cr isotope analyses}

\subsubsection{Cr double spike and data quality}

Double spike data reduction determines the sample $\mathrm{Cr}$ isotope composition relative to the isotope composition of the National Institute of Standards and Technology (NIST) standard reference material (SRM) $\mathrm{Cr}$ isotope standard 979. Using a double spike facilitates an accurate correction of the laboratory-induced and instrumental fractionation of $\mathrm{Cr}$ isotopes that occurred after addition of the double spike. An aliquot of the same ${ }^{50} \mathrm{Cr}-{ }^{54} \mathrm{Cr}$ double spike used by Schoenberg et al. (2008), originally calibrated against the NIST SRM 3112a, was used for this work and detailed specifications of the double spike are given in Schoenberg et al. (2008) and Døssing et al. (2011). The sample $\mathrm{Cr}$ isotope composition was recalculated relative to the certified NIST SRM 979 (0.00 \pm 0.02\%; Ellis et al., 2002; Schoenberg et al., 2008; Zink et al., 2010) to achieve inter-laboratory comparability and international consistency. Further, to maintain inter-laboratory comparability, we report the $\mathrm{Cr}$ isotope data of our experiments relative to the certified Cr isotope standard NIST SRM 979, also referred to as SRM979 (e.g. Table 1 ), by adding $0.09 \%$ o to the analyzed sample $\delta^{53} \mathrm{Cr}$ results, which we base on repeated double spike analyses of NIST SRM 979 that yielded a mean value of $-0.09 \pm 0.02 \%$ o $(n=12)$ compared to the certified value, i.e. the double spiked NIST SRM 979 was measured to be $\sim 0.09 \%$ heavier. This discrepancy to the certified value for NIST SRM 979 could be due to a minor collector efficiency difference between the TIMS used to calibrate the double spike and the double spike we used for this study.

Table 1

Cr concentrations and isotope compositions of the international carbonate standards JDo-1 and JLs-1.

\begin{tabular}{|c|c|c|c|c|}
\hline & $\begin{array}{l}\mathrm{Cr} \pm 2 \sigma \\
\left(\mu \mathrm{g} \mathrm{g}^{-1}\right)\end{array}$ & $\begin{array}{l}\delta^{53} \mathrm{Cr} \pm 2 \sigma^{\mathrm{a}} \\
(\%, \mathrm{SRM} 979)\end{array}$ & $n(\text { run })^{\mathrm{b}}$ & Reference \\
\hline JDo-1 & $\begin{array}{l}6.83 \pm 0.39 \\
7.26 \pm 0.34 \\
7.93 \pm 0.00 \\
1.14 \pm 0.03 \\
1.05 \pm 0.01 \\
3.37 \pm 0.00\end{array}$ & $\begin{array}{l}+1.70 \pm 0.08 \\
+1.69 \pm 0.05 \\
+1.72 \pm 0.06 \\
+1.90 \pm 0.07 \\
+1.89 \pm 0.02 \\
+1.99 \pm 0.02\end{array}$ & $\begin{array}{l}5 \\
10(3-5) \\
10 \\
3 \\
3(5) \\
1\end{array}$ & $\begin{array}{l}\text { Pereira et al. (2015) } \\
\text { Rodler et al. }(2015)^{c} \\
\text { Bonnand et al. (2011) } \\
\text { Imai et al. (1996) } \\
\text { Pereira et al. (2015) } \\
\text { Rodler et al. (2015) } \\
\text { Bonnand et al. (2011) } \\
\text { Imai et al. (1996) }\end{array}$ \\
\hline $\begin{array}{l}\text { a The } 8 \\
\text { b The } \mathrm{r} \\
\text { solved se } \\
\text { filaments } \\
{ }^{\mathrm{c}} \mathrm{Cr} \text { col }\end{array}$ & $\begin{array}{l}\text { esults are r } \\
\text { er of repeate } \\
\text { ely several } \\
\text { time; run }\end{array}$ & $\begin{array}{l}\text { ed relative to } \\
\text { lyses is indic } \\
\text { and used for } \\
\text { rent runs of t }\end{array}$ & $\begin{array}{l}\mathrm{r} \text { isotope } \\
\mathrm{y}: n=\mathrm{a} \\
\text { rate anal } \\
\text { me filame }\end{array}$ & $\begin{array}{l}\text { lard SRM979. } \\
\text { uot of a sample was di } \\
\text { runs using different } \\
\text { ad. }\end{array}$ \\
\hline
\end{tabular}


To assess our $\mathrm{Cr}$ data quality, we repeatedly treated and analyzed the international carbonate standards JDo- 1 and JLs- 1 along with the sam-

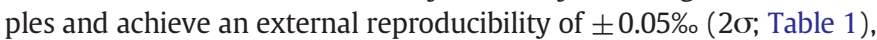
consistent with previous reports (Frei et al., 2011). Our external reproducibility was used for error propagation throughout the paper. The relative standard deviation of $\mathrm{Cr}$ concentration data (1RSD, 5.70\%) was determined using different aliquots and runs for several individual samples of the international carbonate standard JDo-1 (Table 1). Our sample dissolution procedure was also compared to previously published methods ( $0.5 \mathrm{~mol} \mathrm{~L}^{-1} \mathrm{HCl}$; Bonnand et al., 2011) and we found that $\mathrm{Cr}$ concentrations and $\mathrm{Cr}$ isotopic results were within analytical error (Table 1). There are no certified $\delta^{53} \mathrm{Cr}$ values for either of the two international standards. $\mathrm{Cr}$ concentrations of JDo- 1 and JLs- 1 reported here and by Bonnand et al. (2011) are lower than the certified values (Imai et al., 1996), possibly due to incomplete dissolution.

\subsubsection{Sample treatment and separation}

$\mathrm{Cr}$ analyses were performed on aliquots of the cap dolostone sample powders. The samples were weighed to be between $50 \mathrm{mg}$ and $200 \mathrm{mg}$, which we chose so that the sample amount would correspond to an initial $\mathrm{Cr}$ mass of at least 600 to $1000 \mathrm{ng}$; this was based on Cr concentrations previously determined by means of ICP-OES and/or preliminary TIMS analyses. The samples were doped with an adequate amount of a ${ }^{50} \mathrm{Cr}-{ }^{54} \mathrm{Cr}$ double spike corresponding to a sample to double spike $\mathrm{Cr}$ concentration of approximately 1:4 (Ellis et al., 2002; Frei et al., 2013; Schoenberg et al., 2008). This was followed by dissolving the carbonate powders for $\sim 10 \mathrm{~min}$ in $100 \mu \mathrm{L}$ of $2 \mathrm{~mol} \mathrm{~L}^{-1} \mathrm{HCl}$ per $100 \mathrm{mg}$ sample inside chemical workstations equipped with better than Class 100 Hepa filters. The samples were treated as outlined by Rodler et al. (2015). In short, the sample solutions (supernatants) were dried on a hotplate at $100^{\circ} \mathrm{C}$, treated with a $1: 3$ solution of concentrated $\mathrm{HNO}_{3}: \mathrm{HCl}$ at $130^{\circ} \mathrm{C}$ to ensure mixing of sample and double spike, then again dried at $100{ }^{\circ} \mathrm{C}$, redissolved in $1 \mathrm{~mL}$ of $6 \mathrm{~mol} \mathrm{~L}^{-1} \mathrm{HCl}$ and kept at $100{ }^{\circ} \mathrm{C}$ overnight prior to cation exchange chromatography (modified after Trinquier et al., 2008). The sample solutions were diluted with ultrapure water to achieve a concentration of $0.5 \mathrm{~mol} \mathrm{~L}^{-1} \mathrm{HCl}$; the first $5 \mathrm{~mL}$ were passed through the cation exchange column and discharged to reduce isobaric interferences and impurities (Trinquier et al., 2008); the remainder of the sample solution $(\sim 6 \mathrm{~mL})$ and a $10 \mathrm{~mL}$ wash of double distilled $0.5 \mathrm{~mol} \mathrm{~L}^{-1} \mathrm{HCl}$ were collected and dried on a hotplate at $\sim 100{ }^{\circ} \mathrm{C}$. The cation exchange resin $(10 \mathrm{~mL}$; Dowex AG $1 \times 8100$ 200 mesh, Bio Rad ${ }^{\mathrm{TM}}$ ) was reused and thus cleaned once prior and twice after each sample separation with $\sim 20 \mathrm{~mL}$ of each $5 \mathrm{~mol} \mathrm{~L}^{-1}$ $\mathrm{HNO}_{3}$, ultrapure water, $6 \mathrm{~mol} \mathrm{~L}-1 \mathrm{HCl}$, and $0.5 \mathrm{~mol} \mathrm{~L}-1 \mathrm{HCl}$. The cation exchange chromatography technique achieved a yield of more than $70 \%$ with a blank of $4.07 \pm 0.63 \mathrm{ng} \mathrm{Cr}$ ( $n=3$, with 5 runs each), significantly low compared to the initial sample amount of 600 to $1000 \mathrm{ng} \mathrm{Cr}$.

\subsubsection{Mass spectrometry}

The $\mathrm{Cr}$ isotope analyses were performed on an IsotopX/GV IsoProbe T TIMS equipped with eight Faraday collectors allowing for simultaneous collection of the four $\mathrm{Cr}$ beams $\left({ }^{50} \mathrm{Cr}^{+},{ }^{52} \mathrm{Cr}^{+},{ }^{53} \mathrm{Cr}^{+},{ }^{54} \mathrm{Cr}^{+}\right)$together with beams of the interfering ${ }^{49} \mathrm{Ti}^{+},{ }^{51} \mathrm{~V}^{+}$, and ${ }^{56} \mathrm{Fe}^{+}$masses. One run consisted of 120 cycles, grouped into 5 cycles of 24 blocks each with $10 \mathrm{~s}$ signal integrations, performed in static mode and including a baseline integration of $20 \mathrm{~s}$. The separated $\mathrm{Cr}$ samples were loaded onto previously outgassed $99.98 \%$ single rhenium filaments in a mixture of ultrapure water, $3 \mu \mathrm{L}$ silicic acid, and $1 \mu \mathrm{L}$ of both $0.5 \mathrm{~mol} \mathrm{~L}^{-1} \mathrm{H}_{3} \mathrm{BO}_{3}$ and $0.5 \mathrm{~mol} \mathrm{~L}^{-1} \mathrm{H}_{3} \mathrm{PO}_{4}$. The samples were analyzed at least three times with a ${ }^{53} \mathrm{Cr}$ ion beam intensity of 500 to $600 \mathrm{mV}$ at a temperature of $1000-1100{ }^{\circ} \mathrm{C}$, double-spike corrected and calculated as described by Schoenberg et al. (2008) and Døssing et al. (2011). Results are reported in $\delta$-notation in permil (\%) with \pm standard deviation $(2 \sigma)$ and with the number of repeated analyses that indicate different runs of the same filament load (run). If a sample was prepared several times, i.e. an aliquot of a sample was dissolved separately several times and used for separate analytical runs using different Re filaments each time, it is signified by $(n)$.

\subsubsection{Cr corrections}

Analyzed $\mathrm{Cr}$ data can be corrected for detrital contamination (e.g. Planavsky et al., 2014; Reinhard et al., 2014) for example using concentrations of the immobile element $\mathrm{Al}$ (e.g. Voegelin et al., 2009; Eroglu et al., 2015; Paulukat et al., 2015), if these are assumed to be detritusrelated. Based on this assumption, detrital contamination can be expressed as a percentage of the analyzed $\mathrm{Cr}$ concentration (Table 2). To correct the analyzed cap dolostone $\mathrm{Cr}$ concentrations and $\delta^{53} \mathrm{Cr}$ values, we use sample $\mathrm{Al}$ concentration as indicator for the degree of shale contamination, shale-typical $\mathrm{Al}$ and $\mathrm{Cr}$ concentrations ( $\mathrm{Al}_{\text {PAAS }}$ and $\mathrm{Cr}_{\text {PAAS }}$ ) of $10 \mathrm{wt} . \%$ and $110 \mu \mathrm{g} \mathrm{g}^{-1}$, respectively; Taylor and McLennan, 1985; McLennan, 1989) and the mean $\delta^{53} \mathrm{Cr}$ value for the bulk silicate Earth (BSE) of $-0.124 \%$ 。 $\left(\delta^{53} \mathrm{Cr}_{\mathrm{BSE}}\right.$; Schoenberg et al., 2008) that was recently confirmed by Wang et al. (2016). This is also used to distinguish negatively and positively fractionated $\delta^{53} \mathrm{Cr}$ values, where the former defines $\delta^{53} \mathrm{Cr}$ values within or below the range of BSE and the latter refers to $\delta^{53} \mathrm{Cr}$ values that are higher than the $\delta^{53} \mathrm{Cr}$ range of BSE.

To correct analyzed $\mathrm{Cr}$ concentrations $(\mathrm{Cr})$ to authigenic values $\left(\mathrm{Cr}_{\text {auth }}\right)$, we first calculated the detrital $\mathrm{Cr}$ fraction $\left(\mathrm{Cr}_{\mathrm{det}}\right)$ with the help of sample $\mathrm{Al}$ concentrations ( $\mathrm{Al}$ ), shale-typical concentrations and subsequently subtracting this fraction from the analyzed $\mathrm{Cr}$ values $((1))$. The detrital $\mathrm{Cr}$ contents $\left(\mathrm{Cr}_{\operatorname{det}}\right.$ given in \%) are then calculated from analyzed and detrital $\mathrm{Cr}$ concentration ( $\mathrm{Cr}$ and $\mathrm{Cr}_{\text {det }}$, respectively) ((2)), which we then use to correct analyzed $\delta^{53} \mathrm{Cr}$ values to $\delta^{53} \mathrm{Cr}_{\text {auth }}$ $((3))$.

$C r_{\text {auth }}=C r-\left(C r_{\mathrm{PAAS}} *\left(A l / A l_{\mathrm{PAAS}}\right)\right)$

$C r_{\text {det }}(\%)=C r_{\text {det }} /(C r / 100)$

$f 1=\mathrm{Cr}_{\text {det }} / 100$

$\delta^{53} C r_{\text {auth }}=\frac{\left(\delta^{53} C r *\left(f 1 * C r_{\text {det }}+(1-f 1) * C r_{\text {auth }}\right)-\left(\delta^{53} C r_{B S E} * C r_{\text {det }} * f 1\right)\right)}{\left(C r_{\text {auth }} *(1-f 1)\right)}$

Analyzed and authigenic $\mathrm{Cr}$ concentrations and $\delta^{53} \mathrm{Cr}$ values are listed in Table 2 together with detrital $\mathrm{Cr}$ contents $\left(\mathrm{Cr}_{\text {det }}\right.$ given in \%).

\section{Results}

We analyzed $\mathrm{Cr}$ concentration and isotopic composition of 5 cap dolostones pertaining to the Yanwutan section (YAW samples; Table 2) and 7 cap dolostones pertaining to the Jijiawan section (JJW samples; Table 2), which have been described in detail (C-, O-, Sr isotopic composition, major and trace elements as well as rare earth elements (REE)) by Guo et al. (2007), Hohl et al. (2015) and Hohl et al. (under review). The $\delta^{13} \mathrm{C}_{\text {carb }}$ values of YAW samples previously reported by Guo et al. (2007) are initially lighter and increase towards heavier values at the end of the section, similar to $\delta^{18} \mathrm{O}_{\text {carb }}$ values (Table 3 ). TOC values of cap dolostones pertaining to the YAW section are generally low ( $<1 \%$; Table 3; Guo et al., 2007) and there is no correlation between $\delta^{13} \mathrm{C}_{\text {carb }}$ signatures and TOC values or between TOC values and $\delta^{53} \mathrm{Cr}$ signals (Tables 2 and 3 ). Heavier $\delta^{18} \mathrm{O}_{\text {carb }}$ values show a positive correlation to increasingly higher $\delta^{53} \mathrm{Cr}$ values for samples pertaining to the YAW section $\left(r^{2}=0.80, p<0.05, n=5\right.$; Fig. 3 ), although these are still within the $\delta^{53} \mathrm{Cr}$ range of BSE when considering the external reproducibility of our results ( $\pm 0.05 \%$ o). JJW samples show typically light $\delta^{13} \mathrm{C}_{\text {carb }}$ values ( - 4\%; Table 3) and light $\delta^{18} \mathrm{O}_{\text {carb }}$ values ( - 7\%; Table 3). 
Table 2

Cr concentrations and isotope compositions with Al-based corrections.

\begin{tabular}{|c|c|c|c|c|c|c|c|c|c|}
\hline Sample & Stratigraphic height (m) & Lithology & $\begin{array}{l}\mathrm{Cr}^{\mathrm{a}} \\
\left(\mu \mathrm{g} \mathrm{g}^{-1}\right)\end{array}$ & $\begin{array}{l}\delta^{53} \mathrm{Cr} \pm 2 \sigma^{\mathrm{b}} \\
(\%, \text { SRM979) }\end{array}$ & run $^{\mathrm{c}}$ & $\begin{array}{c}\mathrm{Al}^{\mathrm{d}} \\
\left(\mu \mathrm{g} \mathrm{g}^{-1}\right)\end{array}$ & $\begin{array}{l}\mathrm{Cr}_{\text {auth }} \\
\left(\mu \mathrm{g} \mathrm{g}^{-1}\right)\end{array}$ & $\begin{array}{l}\delta^{53} \mathrm{Cr}_{\text {auth }} \\
\text { (\%。) }\end{array}$ & $\begin{array}{l}\mathrm{Cr}_{\text {det }} \\
(\%)\end{array}$ \\
\hline YAW500 & 0.00 & Cap dolostone & 2.38 & $-0.27 \pm 0.03$ & 2 & 955.55 & - & - & $>40$ \\
\hline YAW501 & 1.70 & Cap dolostone & 5.61 & $-0.11 \pm 0.03$ & 3 & 327.03 & 5.25 & -0.11 & 6.41 \\
\hline YAW503 & 3.90 & Cap dolostone & 0.41 & $-0.16 \pm 0.01$ & 3 & 438.28 & - & - & $>40$ \\
\hline YAW504 & 5.20 & Cap dolostone & 5.63 & $+0.02 \pm 0.04$ & 3 & 309.52 & 5.29 & +0.02 & 6.04 \\
\hline YAW505 & 6.40 & Cap dolostone & 4.31 & $-0.04 \pm 0.03$ & 3 & 846.23 & 3.38 & -0.03 & 21.59 \\
\hline JJW0.0 & 0.00 & Cap dolostone & 0.64 & $-0.05 \pm 0.02$ & 4 & 147.89 & 0.41 & -0.03 & 35.90 \\
\hline JJW0.2 & 1.33 & Cap dolostone & 1.67 & $-0.68 \pm 0.00$ & 2 & 209.34 & 1.43 & -0.69 & 14.70 \\
\hline JJW0.35 & 2.14 & Cap dolostone & 2.40 & $-0.34 \pm 0.03$ & 3 & 223.42 & 2.04 & -0.34 & 15.06 \\
\hline JJW0.4 & 2.28 & Cap dolostone & 1.78 & $-0.26 \pm 0.00$ & 4 & 328.37 & 1.43 & -0.27 & 19.97 \\
\hline JJW0.5 & 2.56 & Cap dolostone & 3.27 & $-0.18 \pm 0.01$ & 2 & 323.79 & 2.72 & -0.18 & 16.73 \\
\hline JJW0.7 & 3.25 & Cap dolostone & 4.42 & $-0.32 \pm 0.01$ & 3 & 497.00 & 3.99 & -0.32 & 9.74 \\
\hline JJW0.95 & 3.80 & Cap dolostone & 0.70 & $-0.19 \pm 0.06$ & 2 & 391.13 & - & - & $>40$ \\
\hline
\end{tabular}

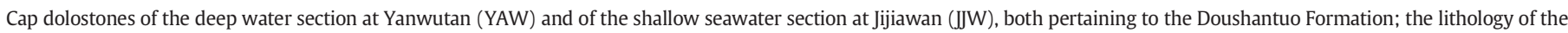
YAW section is adapted from Guo et al. (2007), the lithology of the JJW section is from Hohl et al. (under review).

${ }^{a} \mathrm{Cr}$ concentration data $\left(\mu \mathrm{g} \mathrm{g}^{-1}\right.$ ) have a relative standard deviation (1RSD) of 5.70\% determined using different aliquots and runs for individual JDo-1 samples (Table 1 ).

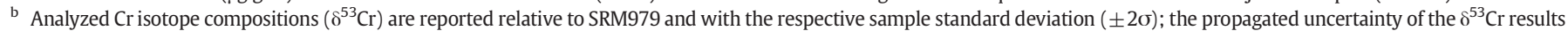
is $\pm 0.05 \%$ o $(2 \sigma)$, based on repeated JDo- 1 analyses (Table 1 ).

c run $=$ number of repeated analyses, i.e. different runs of the same filament load.

${ }^{\mathrm{d}} \mathrm{Al}$ concentration data $\left(\mu \mathrm{g} \mathrm{g}^{-1}\right.$ ) have a relative standard deviation (1RSD) of $<5 \%$ (JDo-1); authigenic $\mathrm{Cr}$ concentrations, $\delta^{53} \mathrm{Cr}_{\text {and detrital }} \mathrm{Cr}_{\text {contribution }}\left(\mathrm{Cr}_{\text {auth }}, \delta^{53} \mathrm{Cr}_{\text {auth }}\right.$ and $\mathrm{Cr}_{\text {det }}$, respectively) were calculated as outlined in Section 3.2.4; $\mathrm{Cr}$ corrections are omitted when $\mathrm{Cr}_{\mathrm{det}}>40 \%$.

The cap dolomites of both sections yield largely negatively fractionated $\delta^{53} \mathrm{Cr}$ signals (Fig. 2), i.e. $\delta^{53} \mathrm{Cr}$ values in the range of BSE. Two samples are slightly heavier than BSE ( - 0.04\%; YAW505, JJW0.0; Table 2), and one sample yielded a slightly positively fractionated $\delta^{53} \mathrm{Cr}$ value (YAW504: $+0.02 \pm 0.04 \%$; Table 2 ). However, taking our external reproducibility of $\pm 0.05 \%$ into consideration, these samples are still within the range of BSE. Cr concentrations are generally high throughout the cap dolomite sequence (up to $5.6 \mu \mathrm{g} \mathrm{g}^{-1}$; Fig. 2) with only four samples with $\mathrm{Cr}$ concentrations $<1.0 \mu \mathrm{g} \mathrm{g}^{-1}$ (Table 2). Al concentrations of the dissolved samples range between $\sim 150 \mu \mathrm{g} \mathrm{g}^{-1}$ and up to $\sim 950 \mu \mathrm{g} \mathrm{g}^{-1}$ (Table 2) and are generally lower in samples of the Jijiawan section (JJW). Ti concentrations of the dissolved samples range from $\sim 2 \mu \mathrm{g} \mathrm{g}^{-1}$ up to $\sim 216 \mu \mathrm{g} \mathrm{g}^{-1}$ (Table 3) with slightly lower values for samples of the JJW section. There is no significant covariation between $\mathrm{Ti}$ and $\mathrm{Cr}$ concentrations or between Ti concentrations and $\delta^{53} \mathrm{Cr}$ values in the entire data set, and also not for samples of the individual cap dolostone sections (not shown). Some samples of the JJW section show higher $\mathrm{Cr}$ concentrations and isotopically lighter $\delta^{53} \mathrm{Cr}$ values coinciding with higher Al concentrations (Table 2), but neither $\mathrm{Cr}$ concentrations nor $\delta^{53} \mathrm{Cr}$ values are statistically significantly correlated with $\mathrm{Al}$ concentrations; $\delta^{53} \mathrm{Cr}$ values of the JJW section are strongly negatively fractionated with some values even below the $\delta^{53} \mathrm{Cr}$ range expected for BSE (e.g. JJW0.2; Table 2). Samples of the YAW section show a similar tendency of decreasing Al concentrations with increasing $\delta^{53} \mathrm{Cr}$ values. The Al-based corrections that we employ to reduce the influence of detrital contamination slightly increase some of the $\mathrm{Cr}$ isotopic signals and generally decrease $\mathrm{Cr}$ concentrations, although authigenic signals still largely follow the trend of analyzed values (Fig. 2).

Al-based corrections of $\mathrm{Cr}$ signals are challenging and not possible for all studied cap dolomites pertaining to the Doushantuo Formation due to largely negatively fractionated $\mathrm{Cr}$ isotopic signals and high detrital $\mathrm{Cr}$ contents $\left(\mathrm{Cr}_{\mathrm{det}}\right)$. Here, a conservative cut-off is proposed at $\mathrm{Cr}_{\mathrm{det}}$ above $40 \%$ (Table 2 ). The corrected $\mathrm{Cr}$ isotope values are only slightly higher than the analyzed $\delta^{53} \mathrm{Cr}$ values that were just within the range of BSE (YAW504, YAW505, JJW0.0; Table 2). Of these slightly positively fractionated $\delta^{53} \mathrm{Cr}_{\text {auth }}$ values, sample YAW504 yielded the highest analyzed (as well as corrected) $\delta^{53} \mathrm{Cr}$ value $(\sim+0.02 \%$; Table 2$)$ of the studied cap dolostone sections, concurrent with the highest $\mathrm{Cr}$ - and the lowest $\mathrm{Al}$ concentration recorded in the YAW section $\left(5.63 \mu \mathrm{g} \mathrm{g}{ }^{-1}\right.$ and $\sim 300 \mu \mathrm{g} \mathrm{g}^{-1}$, respectively; Table 2). This sample also has a relatively heavy $\delta^{18} \mathrm{O}_{\text {carb }}$ value $(-4.5 \%$; Table 3$)$ compared to other cap

Table 3

Element abundances and isotopic compositions ( $\mathrm{Sr}, \mathrm{C}, \mathrm{O})$ of cap dolostones from the Yanwutan and Jijiawan section.

\begin{tabular}{|c|c|c|c|c|c|c|c|c|c|c|c|c|}
\hline Sample & $\begin{array}{l}\mathrm{Ti}^{\mathrm{a}} \\
\left(\mu \mathrm{g} \mathrm{g}^{-1}\right)\end{array}$ & $\begin{array}{l}\mathrm{Sr}^{\mathrm{b}} \\
\left(\mu \mathrm{g} \mathrm{g}^{-1}\right)\end{array}$ & $\mathrm{Mn} / \mathrm{Sr}^{\mathrm{a}}$ & ${ }^{87} \mathrm{Sr} /{ }^{86} \mathrm{Sr}^{\mathrm{a}}$ & $\begin{array}{l}\delta^{13} C_{\text {carb }}{ }^{c} \\
(\%, \text { VPDB) }\end{array}$ & $\begin{array}{l}\delta^{18} \mathrm{O}_{\text {carb }}{ }^{\mathrm{c}} \\
(\% \text {, VPDB) }\end{array}$ & $\begin{array}{l}\text { TOC } \\
\text { (wt.\%) }\end{array}$ & $\Sigma \mathrm{REE}^{\mathrm{a}}$ & $\mathrm{Y} / \mathrm{Ho}^{\mathrm{a}}$ & $\left(\mathrm{Ce} / \mathrm{Ce}^{*}\right)_{S \mathrm{~N}}^{\mathrm{a}}$ & $\left(\mathrm{Eu} / \mathrm{Eu}^{*}\right)_{\mathrm{SN}}{ }^{\mathrm{a}}$ & $\begin{array}{l}\text { Dol }^{\mathrm{a}} \\
(\mathrm{wt} . \%)\end{array}$ \\
\hline YAW500 & 1.87 & 36.57 & 17.90 & 0.72170 & -4.1 & -10.0 & 0.11 & 1.32 & 0.99 & 0.94 & 1.32 & 0.59 \\
\hline YAW501 & - & 197.24 & - & - & -3.6 & -8.7 & 0.32 & - & - & - & - & - \\
\hline YAW503 & 34.70 & 107.81 & 18.14 & 0.71392 & -3.6 & -9.2 & 0.60 & 1.38 & 1.34 & 0.95 & 1.38 & 0.97 \\
\hline YAW504 & - & 363.41 & - & - & -1.5 & -4.5 & 0.44 & - & - & - & - & - \\
\hline YAW505 & 216.00 & 277.36 & 8.70 & 0.70775 & +1.1 & -4.0 & 0.37 & 1.94 & 1.29 & 0.94 & 1.94 & 0.97 \\
\hline JJW0.0 & 18.10 & 123.79 & 0.35 & 0.71039 & -3.5 & -6.5 & - & 0.10 & 0.35 & 0.63 & 1.27 & 0.51 \\
\hline JJW0.2 & 2.31 & 70.87 & 1.21 & 0.71109 & -2.8 & -6.3 & - & 1.45 & 1.21 & 0.91 & 1.27 & 0.50 \\
\hline JJW0.35 & 1.74 & 68.54 & 1.19 & 0.71194 & -4.0 & -7.2 & - & 1.69 & 1.19 & 0.80 & 1.19 & 0.44 \\
\hline JJW0.4 & 4.62 & 58.93 & 1.30 & 0.71148 & -3.9 & -7.6 & - & 1.99 & 1.30 & 0.85 & 1.16 & 0.50 \\
\hline JJW0.5 & 3.36 & 70.71 & 1.29 & 0.71090 & -4.0 & -5.4 & - & 1.81 & 1.29 & 0.82 & 1.09 & 0.50 \\
\hline JJW0.7 & 7.40 & 56.03 & 1.29 & 0.71087 & -4.4 & -8.2 & - & 1.59 & 1.29 & 0.80 & 1.14 & 0.43 \\
\hline JJW0.95 & 12.40 & 63.16 & 1.20 & 0.71224 & -4.2 & -8.5 & - & 2.25 & 1.20 & 0.79 & 0.92 & 0.48 \\
\hline
\end{tabular}

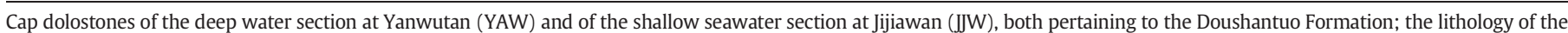

YAW section is adapted from Guo et al. (2007), the JJW samples are described by Hohl et al. (under review); missing values = not analyzed.

a Ti concentrations, Mn/Sr ratios, REE results ( $\left.\mathrm{RREE},(\mathrm{Ce} / \mathrm{Ce})_{\mathrm{SN}},\left(\mathrm{Eu} / \mathrm{Eu}^{*}\right)_{\mathrm{SN}}\right)$ and dolomite fraction (Dol) given in weight \% (wt.\%) were analyzed and previously published by Hohl et al. (2015) and Hohl et al. (under review).

b $\mathrm{Sr}$ concentration data $\left(\mu \mathrm{g} \mathrm{g}^{-1}\right)$ were analyzed at the University of Copenhagen.

${ }^{c} \delta^{13} \mathrm{C}_{\text {carb }}$ and $\delta^{18} \mathrm{O}_{\text {carb }}$ results are reported in \% relative to VPDB; TOC values, $\delta^{13} \mathrm{C}_{\text {carb }}$ and $\delta^{18} \mathrm{O}_{\text {carb }}$ values for YAW samples are from Guo et al. (2007), the JJW results are from Hohl et al. (under review). 


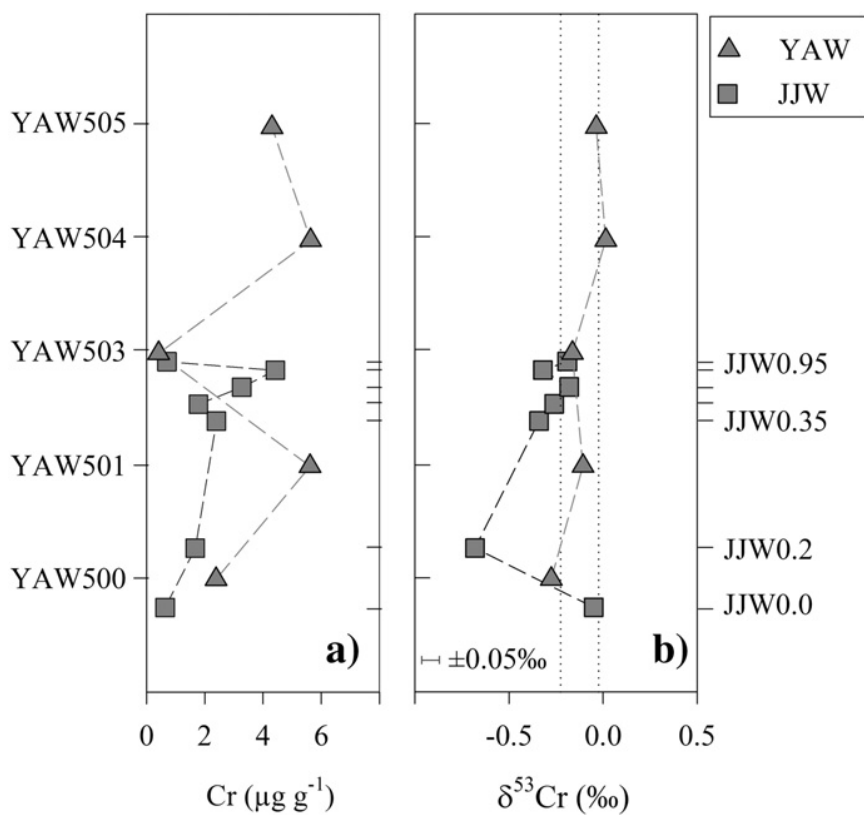

Fig. 2. Chromium stratigraphy of the Yanwutan (YAW) and Jijiawan (JJW) cap dolostone sections pertaining to the Doushantuo Formation: (a) analyzed $\mathrm{Cr}$ concentrations ( $\mu \mathrm{g} \mathrm{g}^{-1}$; Table 1 ); (b) analyzed $\delta^{53} \mathrm{Cr}$ values (given in \%, relative to SRM979; Table 1) where the error bar at the bottom indicates the external reproducibility $( \pm 0.05 \%, 2 \sigma)$ that is generally higher than the sample standard error except for sample JJW0.95 ( $\pm 0.06 \%$, Table 2$)$; the vertical dashed lines in (b) indicate the $\delta^{53} \mathrm{Cr}$ range of BSE $(-0.124 \pm 0.101 \%$; Schoenberg et al., 2008); the relative standard deviation of $\mathrm{Cr}$ concentration data (5.70\%) and the external reproducibility of $\mathrm{Cr}$ isotope data $( \pm 0.05 \%$, $2 \sigma)$ are based on multiple analyses of the international carbonate standard JDo- 1 (Table 1); the position of samples presented in this figure correlates to their position in the schematic stratigraphic column and to their deposition on the Yangtze Platform (see Fig. 1b).

dolostones of the two studied sections. The other slightly positively fractionated $\delta^{53} \mathrm{Cr}_{\text {auth }}$ value of a sample from the YAW section (YAW505) also has a high $\mathrm{Cr}$ concentration, but in contrast to the above mentioned sample (YAW504), is also characterized by an increased Al concentration translating into an increased proportion of $\mathrm{Cr}_{\text {det }}$ (Table 2). However, this sample shows a ${ }^{87} \mathrm{Sr} /{ }^{86} \mathrm{Sr}$ signal of 0.70775 , which is within the range expected of Ediacaran seawater, and exhibits relatively high $\mathrm{Sr}$ concentrations as well as seawater $\delta^{13} \mathrm{C}_{\text {carb }}$ and $\delta^{18} \mathrm{O}_{\text {carb }}$ values (Table 3; Hohl et al., 2015).

The sample with a positively fractionated $\delta^{53} \mathrm{Cr}_{\text {auth }}$ value pertaining to the JJW section (JJW0.0) shows a relatively low $\mathrm{Cr}$ concentration and high $\mathrm{Cr}_{\text {det }}$ (Table 2), but is also characterized by a distinct negative Ce anomaly $\left(\left(\mathrm{Ce} / \mathrm{Ce}^{*}\right)_{\mathrm{SN}}=0.63\right)$, a negative $\mathrm{Y}$ anomaly $\left(\mathrm{Y} / \mathrm{Ho}_{\mathrm{SN}}\right.$ ratio of 0.35 ) and relatively low $\Sigma$ REE (Table 3; Hohl et al., 2015; Hohl et al., under review). Cap dolostone $\mathrm{Y} / \mathrm{Ho}$ ratios are generally superchondritic and Eu anomalies are positive throughout both sections (Table 3; Hohl et al., 2015; Hohl et al., under review). The JJW cap dolostones generally show real negative Ce anomalies (Fig. 3; Hohl et al., 2015), with (Ce/ $\left.\mathrm{Ce}^{*}\right)_{\text {SN }}$ values $<0.9$ (Table 3 ), whereas YAW samples show positive $\mathrm{Ce}$ anomalies (>0.9; Table 3; Hohl et al., 2015). Samples of the YAW section further yield a more pronouncedly dolomitic fraction (dolomite fractions are given in wt.\% in Table 3) and are characterized by higher $\mathrm{Mn} / \mathrm{Sr}$ ratios (Table 3) compared to samples of the JJW section. Generally, ${ }^{87} \mathrm{Sr} /{ }^{86} \mathrm{Sr}$ ratios in both cap dolostone sections (Table 3) are higher than expected for Ediacaran seawater values (Fig 3) and Sr concentrations are well below $400 \mu^{\prime g ~ g}{ }^{-1}$ (Table 3). Furthermore, decreasing Sr concentrations in the YAW section are pronouncedly positively correlated with decreasing $\delta^{53} \mathrm{Cr}$ values $\left(\mathrm{r}^{2}=0.97, p<0.05, n=5\right.$; Fig 3$)$ and with decreasing $\mathrm{Cr}$ concentrations $\left(\mathrm{r}^{2}=0.56, p<0.05, n=5\right.$; Fig. 4); decreasing $\delta^{53} \mathrm{Cr}$ values of YAW samples also weakly correlate with decreasing $\mathrm{Cr}$ concentrations ( $r^{2}=0.45, p<0.05, n=5$; Fig. 4).

\section{Discussion}

The light $\mathrm{Cr}$ isotope $\left({ }^{52} \mathrm{Cr}\right)$ is assumed to be preferentially retained with $\mathrm{Cr}(\mathrm{III})$ within the weathered soil whereas the oxidized and mobilized $\mathrm{Cr}(\mathrm{VI})$ is enriched in the heavy ${ }^{53} \mathrm{Cr}$ isotope (Izbicki et al., 2008; Crowe et al., 2013; Frei and Polat, 2013; Berger and Frei, 2014) and transported - potentially without significant isotope effect during adsorption onto particles (Ellis et al., 2004) - via river water to the open ocean (Bonnand et al., 2013; Frei et al., 2014; Paulukat et al., 2015). There, oxygenated water stabilizes the transported $\mathrm{Cr}$ signal

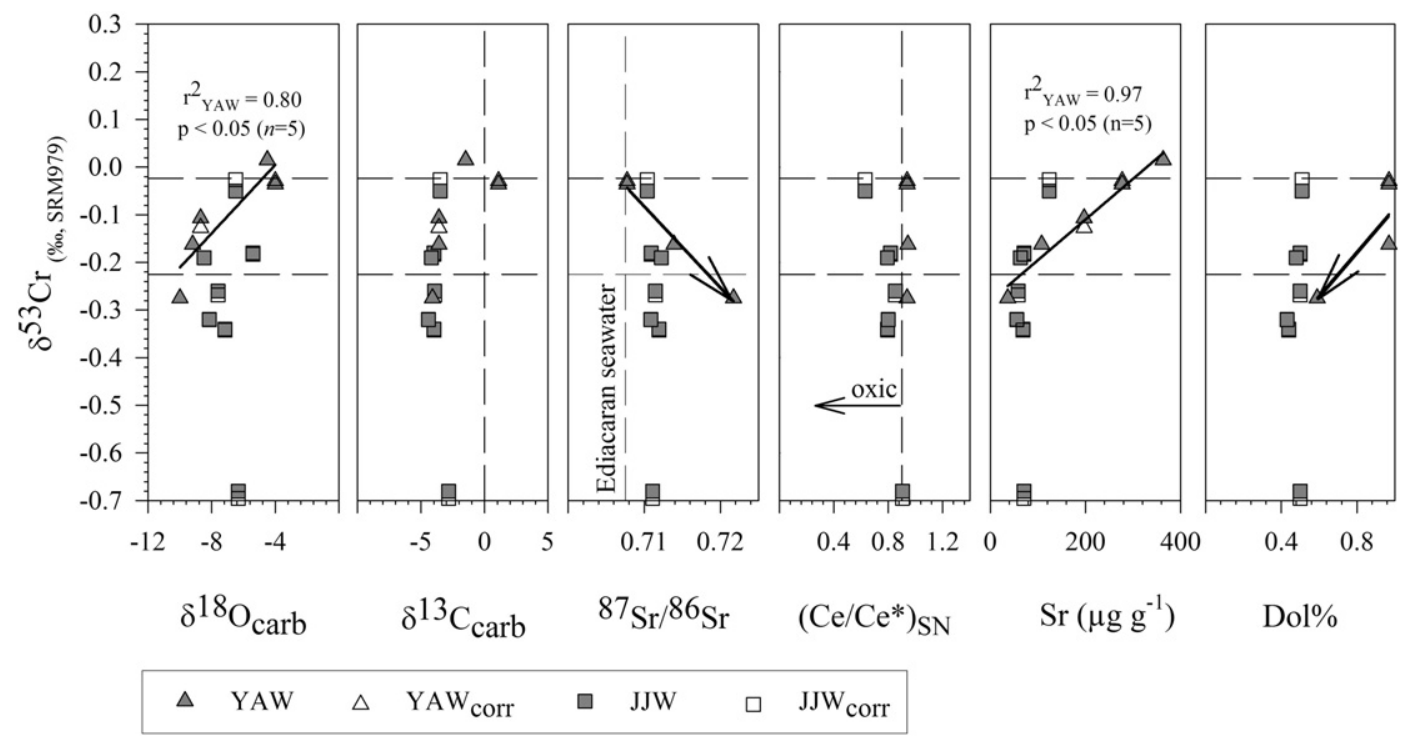

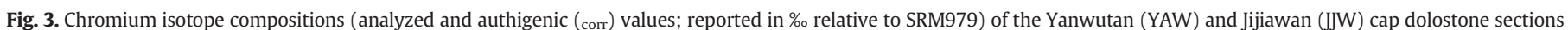

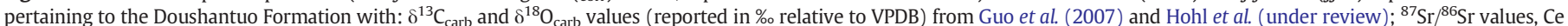

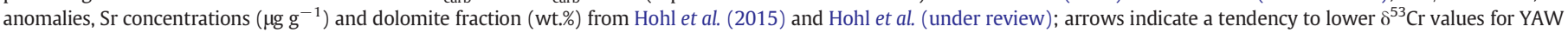

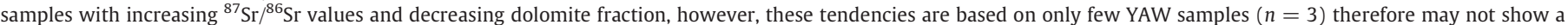

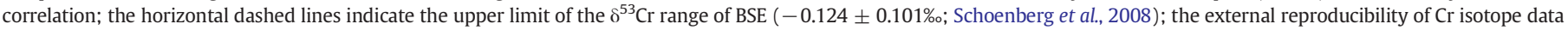

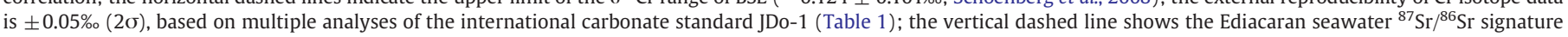
(Jacobsen and Kaufman, 1999). 


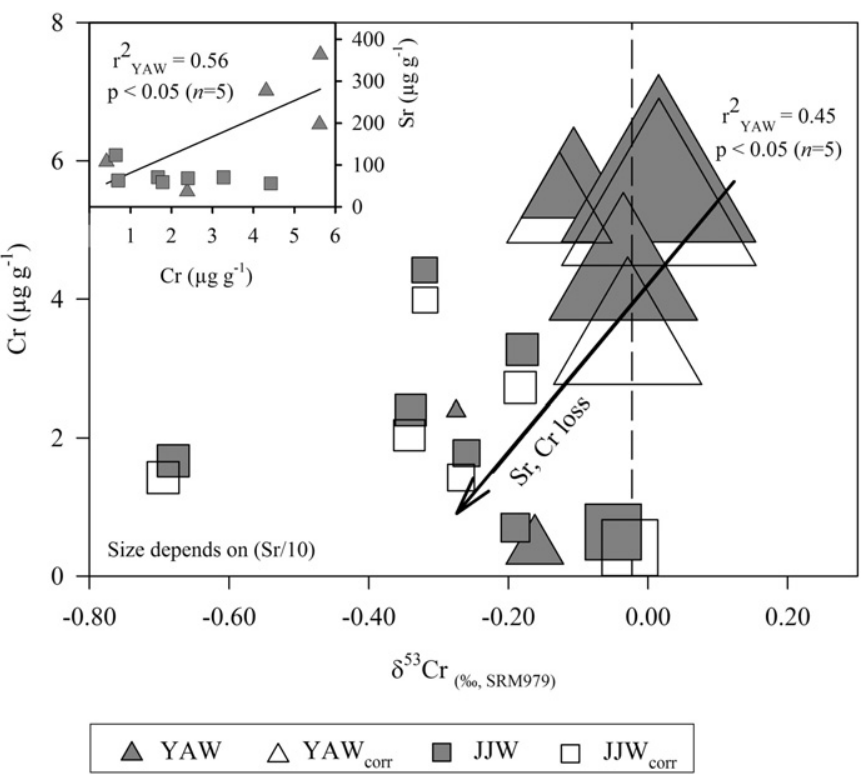

Fig. 4. Chromium concentrations and isotope compositions (analyzed and authigenic (corr) values) of the Yanwutan (YAW) and Jijiawan (JJW) cap dolostone sections pertaining to the Doushantuo Formation depending on $\mathrm{Sr}$ concentration $\left(\mu \mathrm{g} \mathrm{g}^{-1}\right)$ and $\mathrm{Cr}$ concentration ( $\mu \mathrm{g} \mathrm{g}^{-1}$ ) plotted with $\mathrm{Sr}$ concentrations in the upper left corner; the arrow shows a correlation between decreasing $\delta^{53} \mathrm{Cr}$ values and decreasing $\mathrm{Cr}$ concentrations, where a loss of $\mathrm{Cr}$ and concomitant loss of $\mathrm{Sr}$ (symbol size indicates $\mathrm{Sr}$ / 10 ) is possibly correlated to lighter $\delta^{53} \mathrm{Cr}$ values; the vertical dashed lines indicate the $\delta^{53} \mathrm{Cr}$ range of BSE $(-0.124 \pm 0.101 \%$; Schoenberg et al., 2008); $\mathrm{Cr}$ isotope compositions are reported in \% relative to SRM979; the relative standard deviation of $\mathrm{Cr}$ concentration data is $5.70 \%$, the external reproducibility of $\mathrm{Cr}$ isotope data is $\pm 0.05 \%$ 。 $(2 \sigma)$, both are based on multiple analyses of the international carbonate standard JDo- 1 (Table 1).

and carbonates eventually capture the $\mathrm{Cr}$ isotope signature of $\mathrm{Cr}$ that was previously mobilized as a result of oxidative weathering on land (Frei et al., 2011; Bonnand et al., 2013).

River waters supply $~ 90 \%$ of dissolved $\mathrm{Cr}$ to seawater (Chester and Murphy, 1990), predominantly as $\mathrm{Cr}(\mathrm{VI})$ (e.g. Connelly et al., 2006; Lilli et al., 2015) - although both environmentally stable Cr oxidation states can be predominant in aquatic systems depending on the prevailing Eh and pH conditions (Sander and Koschinsky, 2000; van Zuilen and Schoenberg, 2013). Seawater $\delta^{53} \mathrm{Cr}$ signals have shown to correlate with seawater $\mathrm{Cr}$ concentrations, although regionally variable, and dependent on $\mathrm{Cr}$ sourced from different drainage systems (Bonnand et al., 2013, and references therein; Scheiderich et al., 2015), on water depth and on water mass mixing scenarios (Scheiderich et al., 2015). The technique used for obtaining river water samples and sample treatment prior to Cr analyses (Cădkóva and Chrastný, 2015) potentially also influence the $\mathrm{Cr}$ isotopic composition of water samples.

To date, ooids are the only modern marine carbonates analyzed for their $\mathrm{Cr}$ signature. They are typically enriched in $\mathrm{Cr}$ (ooids: 2.6 to $4.0 \mu \mathrm{g} \mathrm{g}^{-1}$; Bonnand et al., 2013) compared to ambient seawater $\left(2-3 \times 10^{4}\right.$ times lower; Bonnand et al., 2013), consistent with $\mathrm{Cr}$ enrichment in synthetically prepared calcite (Rodler et al., 2015, and references therein). A coupled enrichment in $\mathrm{Cr}$ concentration with positively fractionated $\delta^{53} \mathrm{Cr}$ values is also characteristic for international carbonate standards, for example JDo-1 (Permian dolostone) and JLs1 (Triassic limestone) with certified $\mathrm{Cr}$ concentrations of $7.93 \mu \mathrm{g} \mathrm{g}^{-1}$ and $3.37 \mu \mathrm{g} \mathrm{g}^{-1}$, respectively (Imai et al., 1996), and highly positively fractionated $\delta^{53} \mathrm{Cr}$ values ( $>+1.7 \%$; Table 1 , and references therein). Neoproterozoic carbonates analyzed so far, however, have $\mathrm{Cr}$ concentrations that are within the range of those of modern marine carbonate Cr concentrations (Bonnand et al., 2013) or have even higher Cr concentrations (Frei et al., 2011). Furthermore, Rodler et al. (in revision) report a tendency towards more negatively fractionated $\delta^{53} \mathrm{Cr}$ values with increasing $\mathrm{Cr}$ concentrations in carbonates from the Otavi Group,
Namibia, and argue that an increase in $\mathrm{Cr}$ above $1 \mu \mathrm{g} \mathrm{g}^{-1}$ is possibly due to an enhanced contribution of $\mathrm{Cr}$ from detrital material, e.g. from negatively fractionated $\mathrm{Cr}$ (III) adsorbed to clay minerals (Condie and Wronkiewicz, 1990, and references therein; Garnier et al., 2013; Morrison et al., 2015). Here, we report positivley fractionated $\mathrm{Cr}$ isotope singals characteristic for an oxygenated environment and investigate the otherwise largely negativly fractionated $\mathrm{Cr}$ isotope signals of two cap dolostone sections pertaining to the Doushantuo Formation in regard to a possible overprint by (i) detrtital contamination and (ii), explore the influence of diagenetic alteration and post-depositional remobilization of (isotopically heavy) $\mathrm{Cr}$.

\subsection{Detrital contamination}

Negatively fractionated $\delta^{53} \mathrm{Cr}$ values of marine carbonates were previously argued to be due to a significant contribution from hydrothermal systems (Frei et al., 2009, 2011). Dissolution under acid weathering conditions (rather than redox-induced mobilization) was proposed to explain the largely unfractionated Archean BIF-hosted $\mathrm{Cr}$ (Konhauser et al., 2011). Acid dissolution of $\mathrm{Cr}$ as $\mathrm{Cr}$ (III) would not induce any significant $\mathrm{Cr}$ isotope fractionation compared to $\mathrm{BSE} \delta^{53} \mathrm{Cr}$ values (Crowe et al., 2013; van Zuilen and Schoenberg, 2013) and could be facilitated by sulfuric acid production during the oxidation of pyrite (e.g. suggested for the Great Oxidation Event; Konhauser et al., 2011). A so-generated sulfuric acid, however, could be neutralized already within the $\mathrm{Cr}$ (III)-bearing source rocks (Frei et al., 2014) and would then therefore not likely be a significant source of $\mathrm{Cr}$ (III) with a BSE-type $\delta^{53} \mathrm{Cr}$ signature.

Hydrothermal input is considered to have played an important role in regulating ocean chemistry during Neoproterozoic glaciations that would have caused the ocean to be stagnant and anoxic (e.g. Kirschvink, 1992; Huang et al., 2011). Isotopically light, hydrothermally sourced Cr(III) (e.g. Sander and Koschinsky, 2000, 2011) is potentially particle-reactive and highly mobile below a redoxcline, as it can be transported over long distances even in a fully oxidized ocean when bound onto organic ligands or to sulphide (nano)particles (Sander and Koschinsky, 2000, 2011; Yücel et al., 2011). Upon upwelling into surface layers of the ocean, the so-transported isotopically light $\mathrm{Cr}$ (III) could be oxidized above the redoxcline and subsequently incorporated into carbonate minerals as $\mathrm{Cr}(\mathrm{VI})$ (e.g. Tang et al., 2007; Sánchez-Pastor et al., 2011; Rodler et al., 2015). However, while hydrothermally-derived $\mathrm{Cr}(\mathrm{III})$ is efficiently scavenged in the vicinity of hydrothermal vents due to coprecipitation with metal oxides, for example Fe-Mn oxides, in the modern ocean (German et al., 1991; Rudnicki and Elderfield, 1993; Elderfield and Schultz, 1996), this would have been different in the stratified seawater of the Precambrian. In anoxic deep waters of the Precambrian, hydrothermally-derived $\mathrm{Cr}(\mathrm{III})$ would be rapidly hydrolyzed at circumneutral pH (Ball and Nordstrom, 1998) and would consequently precipitate in the vicinity of vents without being dispersed into the global ocean (Crowe et al., submitted for publicatrion). This scenario would render negatively fractionated $\mathrm{Cr}(\mathrm{III})$ from hydrothermal vents a less significant source for $\mathrm{Cr}$ in the cap dolostones analyzed herein and is consistent with a likely insignificant influence of hydrothermally-derived $\mathrm{Cr}$ to Earth's surficial $\mathrm{Cr}$ isotope cycle based on mass balance calculations recently reported by Wang et al. (2016). Also, a lack of positive (Eu/Eu*) $)_{S N}$ anomalies in the studied cap dolostones (Hohl et al., 2015), otherwise typical of subaqueous hydrothermal vent fluids, suggests that mixing of seawater with ocean-ridge derived hydrothermal fluids is a rather unlikely scenario to explain the isotopically light $\mathrm{Cr}$ analyzed in the cap dolostones herein.

Chromium is also highly abundant in magmatic rocks and clastic sedimentary rocks (Schoenberg et al., 2008), where $\delta^{53} \mathrm{Cr}$ values in the range of BSE can be expected, possibly with the exception of altered ultramafic rocks (Farkaš et al., 2013). Therefore, an enrichment in $\mathrm{Cr}$ concentration without significant $\mathrm{Cr}$ isotope fractionation to increasingly positive values as expected when $\mathrm{Cr}$ (III) is leached, hydrolyzed and 
oxidized during weathering processes on land (Oze et al., 2007; Izbicki et al., 2008; Frei et al., 2009, 2011; Crowe et al., 2013; Frei and Polat, 2013; Berger and Frei, 2014; Paulukat et al., 2015), can be assumed to result from the accumulation of for example weathering-resistant Cr-bearing spinel and/or Cr(III)-bearing silicate minerals (Rai et al., 1989; Oze et al., 2004; Garnier et al., 2008, 2013; Schoenberg et al., 2008; Kelepertzis et al., 2013; Morrison et al., 2015; Wang et al., 2016). Dilution of seawater with freshwater from slowly melting icebergs is indicated for the studied cap dolostones by typical seawater-like REE + Y patterns with generally superchondritic but less than modern marine Y/Ho ratios (Bau and Dulski, 1994; Lawrence and Kamber, 2006), by enhanced $\Sigma$ REE contents and by a negative correlation of $\mathrm{Y} / \mathrm{Ho}$ ratios with whole rock Al concentrations (Hohl et al., 2015). Due to enhanced post-glacial weathering rates (e.g. Hoffman et al., 1998; Hoffman and Schrag, 2002; Kasemann et al., 2005), negatively fractionated $\mathrm{Cr}$-bearing minerals that are less susceptible to weathering could have been contributed in greater abundance during deposition of the cap dolostones studied herein.

We use sample Al concentrations (Table 2) to calculate and correct the $\mathrm{Cr}$ signal for detrital contamination. Generally, Al-based corrections (see Section 3.2.4 for details) reduce $\mathrm{Cr}_{\text {auth }}$ concentrations slightly, whereas some of the $\delta^{53} \mathrm{Cr}_{\text {auth }}$ values are slightly elevated (Table 2). Corrected $\mathrm{Cr}_{\text {auth }}$ concentrations and $\delta^{53} \mathrm{Cr}_{\text {auth }}$ values still follow the trend of analyzed values (Fig. 2), but signals slightly indicative of oxidative weathering and of oxidized surface water become more apparent. Three cap dolostones (YAW500, YAW503 and JJW0.95) show enhanced detrital $\mathrm{Cr}$ (>40\%; Table 2) with relatively low $\mathrm{Cr}$ concentrations and with negatively fractionated $\delta^{53} \mathrm{Cr}$ values - although still within the range of BSE. Here, we assume that the $\mathrm{Cr}$ contribution from detrital material overprints a potentially positively fractionated coeval seawater signal.

\subsection{Post-depositional remobilization of $\mathrm{Cr}$}

Carbonates likely incorporate $\mathrm{Cr}(\mathrm{VI})$ in carbonate positions in the calcite structure, potentially without significant changes in $\mathrm{Cr}$ oxidation state upon incorporation (Tang et al., 2007), whereas $\mathrm{Cr}$ (III) preferentially precipitates on calcite surfaces as oxide hydrocarbonate coating (Tang et al., 2007). Synthetic calcite crystals accumulate $\mathrm{Cr}$ relative to the fluid from which they precipitate (Tang et al., 2007; Hua et al., 2007; Sánchez-Pastor et al., 2011; Dixon et al., 2013; Rodler et al., 2015), consistent with the observation of elevated concentrations of $\mathrm{Cr}$ in natural marine carbonates relative to ambient seawater (Bonnand et al., 2013). Synthetic calcite (Rodler et al., 2015) as well as natural non-skeletal carbonates (Bonnand et al., 2013) show a tendency to preferentially incorporate the heavy ${ }^{53} \mathrm{Cr}$, although only a marginal effect of $\mathrm{Cr}$ incorporation on $\mathrm{Cr}$ isotopic fractionation ( $\leq 0.2$ or $\leq 0.3 \%$ o) would be expected particularly at $\mathrm{Cr}$ concentrations typical for seawater (Bonnand et al., 2013; Rodler et al., 2015). Generally, modern marine carbonates are characterized by $\mathrm{Cr}$ concentrations of $<4.0 \mu \mathrm{g} \mathrm{g}^{-1}$ and by $\delta^{53} \mathrm{Cr}>0.0 \%$ (Bonnand et al., 2013), which is largely consistent with ancient carbonates that formed in oxygenated shallow seawater (Frei et al., 2011). The $\mathrm{Cr}$ isotope composition of ancient marine sediments was previously explored to trace changes of the redox state of paleoenvironments (Frei et al., 2011), as a primary marine signal balanced against detrital contamination and hydrothermal input to the depositional environment (see Section 5.1). The results from two cap dolostone sections studied herein indicate a strong influence of post-depositional alteration, particularly for the deep water cap dolostone section (YAW). This is revealed by trends in concurrent loss in $\mathrm{Sr}$ and $\mathrm{Cr}$ with decreasing $\delta^{53} \mathrm{Cr}$ (Fig. 4) and relatively light $\delta^{18} \mathrm{O}_{\mathrm{carb}}$ signals (Table 3 ), supporting earlier suspicions from observations of a $\delta^{53} \mathrm{Cr}$ evolution across the K-Pg boundary sequence at Stevns Klint, Denmark (Voegelin et al., 2013). The shallow water section (JJW) also has generally low $\mathrm{Sr}$ - and $\mathrm{Cr}$ concentrations with negatively fractionated $\delta^{53} \mathrm{Cr}$ signals (Fig. 4), some even below the range of BSE, indicative of leaching of $\mathrm{Cr}$ with a heavy $\mathrm{Cr}$ isotope signature by continental basin fluids. Cap dolostone $\delta^{18} \mathrm{O}_{\text {carb }}$ signals are generally light in both sections, indicative of diagenetic alteration and meteoric fluid/rock interaction (Brand and Veizer, 1981; Jacobsen and Kaufman, 1999). Fluctuations of $\delta^{18} \mathrm{O}_{\text {carb }}$ signals, $\mathrm{Sr}$ - and $\mathrm{Cr}$ concentrations with $\delta^{53} \mathrm{Cr}$ signals recorded by the studied cap dolostones reveal that the $\mathrm{Cr}$ isotope system is sensitive to the influence of carbonate diagenesis and emphasizes the necessity to carefully evaluate diagenetic alteration when applying the $\mathrm{Cr}$ stable isotope system to ancient carbonates.

Hohl et al. (2015) previously reported systematic variations of ${ }^{87} \mathrm{Sr} /{ }^{86} \mathrm{Sr}$ in the deep water cap dolostone section (YAW samples) with Sr concentrations and $\delta^{18} \mathrm{O}_{\text {carb }}$, which they assumed to be due to variable modification of fluid-mobile elements by either meteoric (low oxygen isotopic compositions; Brand and Veizer, 1981) and/or continental basin fluids (radiogenic Sr compositions; Hohl et al., 2015). Samples of the studied cap dolostone sections are assumed to have undergone carbonate diagenesis, which is evident from the enrichment of (remobilized) redox-sensitive elements due to local hydrothermal and anoxic overprint, particularly in the deep water section where positive Ce anomalies dominate (Hohl et al., 2015; Hohl et al., under review), indicative of anoxic pore water conditions and a chemically stratified basin (Canfield, 1998; Li et al., 2010). Further, no correlations of $\delta^{18} \mathrm{O}_{\text {carb }}$ or ${ }^{87} \mathrm{Sr} /{ }^{86} \mathrm{Sr}$ with seawater REE $+\mathrm{Y}$ proxies (Y/Ho or $\mathrm{Pr} / \mathrm{Yb}$ ) were reported (Hohl et al., 2015; Hohl et al., under review). Despite fluid overprint and carbonate alteration, some cap dolostones might still record (close to) pristine signatures. The deep water section of the Yanwutan (YAW) data set shows at least one sample presumably close to pristine Ediacaran composition (YAW505, Table 3; $\delta{ }^{13} \mathrm{C}_{\mathrm{carb}}=+1.1 \%$, $\delta^{18} \mathrm{O}_{\mathrm{carb}}=-4.0 \%$, Guo et al., 2007; ${ }^{87} \mathrm{Sr} /{ }^{86} \mathrm{Sr}=0.70775, \mathrm{Sr}=318.8 \mu \mathrm{g} \mathrm{g}{ }^{-1}$, Hohl et al., 2015). This sample was corrected for $\mathrm{Cr}$ contributed by contamination with detrital material $\left(\mathrm{Cr}_{\mathrm{det}} \sim 20 \%\right.$; Table 2). The corrected $\mathrm{Cr}_{\text {auth }}$ concentration is relatively high $\left(\sim 3.38 \mu \mathrm{g} \mathrm{g}^{-1}\right.$; Table 2$)$, in the range of more recent international carbonate standards (e.g. JLs-1, Triassic limestone, with a $\mathrm{Cr}$ concentration of $3.37 \mu \mathrm{g} \mathrm{g}^{-1}$, Imai et al., 1996; Table 1; or Cal-S, Miocene limestone, with a $\mathrm{Cr}$ concentration of $2.51 \mu \mathrm{g} \mathrm{g}^{-1}$, Bonnand et al., 2011), and is characterized by a slightly positively fractionated $\delta^{53} \mathrm{Cr}$ signal ( - 0.03\%; Table 2). The sample stratigraphically above YAW505, sample YAW504, shows similar carbon and oxygen isotope compositions $\left(\delta^{13} \mathrm{C}_{\mathrm{carb}}=-1.5 \%\right.$, $\delta^{18} \mathrm{O}_{\mathrm{carb}}=-4.5 \%$, Guo et al., 2007), less detrital $\mathrm{Cr}$ contamination ( $\mathrm{Cr}_{\mathrm{det}} \sim 6 \%$; Table 2 ) with a slightly higher $\mathrm{Cr}_{\text {auth }}$ concentration and a positively fractionated $\delta^{53} \mathrm{Cr}_{\text {auth }}$ signal $\left(5.29 \mu \mathrm{g} \mathrm{g}^{-1}\right.$ and $+0.02 \%$, respectively; Table 2$)$ as well. Values above $0.0 \%$ would be expected for deposition of the carbonates under oxygenated seawater (Bonnand et al., 2013). These two contamination corrected $\delta^{53} \mathrm{Cr}_{\text {auth }}$ values are interpreted to represent the best approximation of pristine Ediacaran $\mathrm{Cr}$ signals, particularly that of sample YAW504, and were used to evaluate diagenetic alteration that possibly affected the cap dolostone $\mathrm{Cr}$ isotope composition in the studied sections.

Consistent with alteration of the $\mathrm{Sr}$ isotopic system, as discussed by Hohl et al. (under review), $\mathrm{Cr}$ could be remobilized in-situ by pore water or by externally derived fluids percolating through clastic sediments and precipitating secondary carbonate minerals. Such processes would then preferably retain light $\mathrm{Cr}$ isotopes whereas heavy $\mathrm{Cr}$ isotopes would be removed. Calcite cement formation, presumably as a result of dedolomitization, is more common in shallow water facies and leads to lower $\mathrm{Sr}$ concentrations and higher $\mathrm{Mn} / \mathrm{Sr}$ (Banner and Hanson, 1990) in respective carbonates. Remobilized $\mathrm{Cr}$ and concurrent removal of a positively fractionated $\delta^{53} \mathrm{Cr}$ signal from chemical sediments could be facilitated by hydrothermal leaching, resulting in an increasing depletion in ${ }^{53} \mathrm{Cr}$. Similar to $\mathrm{Sr}$, $\mathrm{Cr}$ is a fluid-mobile element and its concentration may decrease due to progressing carbonate diagenesis (e.g. Veizer, 1983), particularly in secondary carbonates that form after reaction with fluids in open systems (Brand and Veizer, 1980). Furthermore, the downward flux of $\mathrm{Cr}$ from the upper 
Sargasso Sea was previously correlated to the organic carbon flux (Connelly et al., 2006) and a different organic matter flux between deep and shallow water section (YAW and JJW section, respectively) could potentially have influenced early diagenetic redox processes (similar to e.g. authigenic Mo accumulation in marine carbonates; Eroglu et al., 2015). Organic matter degradation by bacterial activity and thermal maturation has been shown to influence the pore water redox state and could potentially also lead to a decrease in sedimentary organic carbon isotopic compositions (Ader et al., 2009; Freudenthal et al., 2001). In the case of the YAW samples, carbon isotopic data previously reported by Guo et al. (2007) show no correlation between elevated TOC- and $\delta^{13} C_{\text {org }}$ values. Further, thermal maturation of organic matter may have been small as $\mathrm{H} / \mathrm{C}$ ratios in these cap dolostones are generally above $0.2(\mathrm{H} / \mathrm{C}$ values range between 0.31 and 1.76 ; Guo et al., 2007). The $\mathrm{H} / \mathrm{C}$ ratio of carbonate samples can be used as parameter for estimating the preservation state of kerogen (e.g. Hayes et al., 1983), where increasing thermal alteration would lead to decreasing $\mathrm{H} / \mathrm{C}$ ratios. For the cap dolostones of the JJW section, no TOC and H/C ratios were analyzed, however, enrichment factors of $\mathrm{Mn}$, Fe and Mo in carbonate leachates of both sampled sections reveal similar conditions of ferruginous seawater and slightly reducing pore-water leading to the formation of Mn-rich dolomite (Hohl et al., under review). Together with the overall low TOC values of YAW cap dolostones $(<1 \%$; Table 3 ) and elsewhere on the Yangtze Platform (Guo et al., 2007, and references therein) this argues against a lateral organic matter distribution and its subsequent decomposition as a main driver for reductive processes influencing the $\mathrm{Cr}$ isotopic compositions within the studied cap dolostones.

\subsection{Oxidative weathering indicated by $\mathrm{Cr}$ isotopes}

During transport to the oceans, $\mathrm{Cr}(\mathrm{VI})$ is potentially again partially reduced (Ellis et al., 2002; Sikora et al., 2008; Døssing et al., 2011; Kitchen et al., 2012; Basu et al., 2014), which would result in an additional enrichment of the remaining dissolved $\mathrm{Cr}(\mathrm{VI})$ in ${ }^{53} \mathrm{Cr}$, whereas ${ }^{53} \mathrm{Cr}$-depleted $\mathrm{Cr}(\mathrm{III})$ is likely to be precipitated and/or adsorbed (Ellis et al., 2002, 2004; Crowe et al., 2013). The overall $\mathrm{Cr}$ isotope composition of seawater is potentially affected if the influence of the mobile ${ }^{53} \mathrm{Cr}$-enriched $\mathrm{Cr}(\mathrm{VI})$ input is large enough (Crowe et al., 2013). Modern seawater $\delta^{53} \mathrm{Cr}$ signatures reported up to date are rather heterogeneous (e.g. Bonnand et al., 2013; Scheiderich et al., 2015; Paulukat et al., in revision) and might vary with water mass source, water depth, salinity or by the degree of water mass mixing (Scheiderich et al., 2015).

Carbonate REE + Y signatures and Ce-anomalies indicate suboxic- to oxic seawater, mostly anoxic deep water and reducing conditions in pore-water persisting at the Yangtze passive continental margin during the Ediacaran (supported by decoupling of $\delta^{13} \mathrm{C}_{\text {carb }}$ from $\delta{ }^{13} \mathrm{C}_{\text {org }}$ and trace metal enrichments; Hohl et al., 2015). Overall, enrichment factors of redox sensitive element values reported by Hohl et al. (2015) and $\delta^{13} C_{\text {carb }}$ reported by Ader et al. (2009) suggest that the deep water of the Nantuo Basin may have been anoxic well into the upper Doushantuo Formation. Such a scenario is consistent with the stratified basin model by Li et al. (2010). The oxygenation of open continental shelf bottom waters (Doushantuo Formation) was then reported to have happened during the mid-Ediacaran (Shen et al., 2008). As outlined earlier, detrital contamination and postdepositional remobilization of $\mathrm{Cr}$ during carbonate diagenesis strongly affect the $\mathrm{Cr}$ isotope signal recorded by marine sediments, however, two samples of the analyzed cap dolomite sequence pertaining to the deep water section (YAW504 and YAW505; Table 2) and one sample of the shallow marine cap dolostone section (JJW0.0; Table 2) reported herein yield contamination-corrected authigenic $\delta^{53} \mathrm{Cr}_{\text {auth }}$ values that closely resemble a potentially coeval seawater $\mathrm{Cr}$ isotope signal in the range previously reported for Neoproterozoic carbonates (Frei et al., 2011).
These $\delta^{53} \mathrm{Cr}_{\text {auth }}$ values are concurrent with less radiogenic ${ }^{87} \mathrm{Sr} /{ }^{86} \mathrm{Sr}$, heavier $\delta^{18} \mathrm{O}_{\text {carb }}$ values, higher $\mathrm{Cr}$ and $\mathrm{Sr}$ concentrations at unchanged Mn concentrations (Tables 2 and 3 ) indicating a less pronounced influence of fluid flow alteration. One sample of the deep water section further yields a ${ }^{87} \mathrm{Sr} /{ }^{86} \mathrm{Sr}$ signal of 0.70775 (YAW505; Hohl et al., 2015), which is close to early Ediacaran seawater values (Jacobsen and Kaufman, 1999). The cap dolostones of the deep water Doushantuo Formation (YAW section) were previously interpreted to have been deposited under anoxic conditions as inferred from a lack of negative Ce anomalies $\left(\left(\mathrm{Ce} / \mathrm{Ce}^{*}\right)_{\mathrm{SN}}=0.94\right.$, Hohl et al., 2015). However only one sample shows little alteration $\left({ }^{87} \mathrm{Sr} /{ }^{86} \mathrm{Sr}=0.70775, \delta^{18} \mathrm{O}=-4.0 \%\right.$, $\delta^{13} \mathrm{C}_{\mathrm{carb}}=+1.1 \%$; Hohl et al., 2015) whereas the cap dolostones of the shallow water Doushantuo at Jijiawan show less variability in ${ }^{87} \mathrm{Sr} /{ }^{86} \mathrm{Sr}$ and $\mathrm{Mn} / \mathrm{Sr}(<5$; Table 3$)$, suggesting that the deep water sections on the Yangtze Platform differ from cap dolostones at other sections. The positively fractionated $\delta^{53} \mathrm{Cr}_{\text {auth }}$ value of the shallow water section is further concurrent with a low $\mathrm{Y} / \mathrm{Ho}$ ratio (Table 3) indicative of a possible seawater/freshwater mixing (Lawrence and Kamber, 2006) after glacial retreat and shows a pronounced negative Ce anomaly $\left(\left(\mathrm{Ce} / \mathrm{Ce}^{*}\right)_{\mathrm{SN}}=0.63\right.$; Table 3$)$ that is close to that of modern oxidized seawater. This could be an indication of the presence of oxidized surface waters at this time (Ling et al., 2013) and there is a possibility that back-reduction processes during riverine transport would enhance the positively fractionated signal of mobilized $\mathrm{Cr}(\mathrm{VI})$. A scenario of decreased detrital contamination and/or reduced postdepositional remobilization of $\mathrm{Cr}$ with concomitant enhanced oxidative weathering could perhaps explain the $\mathrm{Cr}$ isotope composition of some samples pertaining to the deep water and shallow marine cap dolostone sections of the Doushantuo Formation, which would be supported by the respective detrital-corrected $\delta^{53} \mathrm{Cr}_{\text {auth }}$ signals (Table 2). Another possibility to interpret these 'pulses' of enhanced oxidative weathering indicated by a few least-altered of the studied cap dolostones, could be to use these samples to extrapolate a potentially generally oxygenated depositional environment. Such a scenario would have allowed for the presence of a heavy $\mathrm{Cr}$ isotope seawater composition, which would have subsequently been removed from the majority of the studied cap dolostones due to post-depositional remobilization of $\mathrm{Cr}$ and/or overprinting by detrital contamination, respectively, as outlined before (Sections 5.1 and 5.2). However, the evidence of an isotopically heavy seawater $\mathrm{Cr}$ reservoir and the presented interpretation thereof rests on a rather small number of samples that were less affected by detrital contamination and/or diagenetic alteration.

\section{Conclusion}

$\mathrm{Cr}$ concentrations and chromium isotopic compositions have been determined for cap dolostones pertaining to the Ediacaran Doushantuo Formation deposited on the Yangtze Platform, South China. Generally, $\mathrm{Cr}$ concentrations are high and $\delta^{53} \mathrm{Cr}$ signals are negatively fractionated in the studied cap dolostones of a deep water (Yanwutan section, Hunan province) and a shallow marine section (Jijiawan section, Hubei province). Negatively fractionated $\delta^{53} \mathrm{Cr}$ values that seem to slightly correspond to elevated $\mathrm{Al}$ concentrations are interpreted to indicate an enhanced input from previously weathered detrital phases with a negatively fractionated $\mathrm{Cr}$ isotope composition and/or due to in-situ weathering of the studied cap dolostones during post-depositional weathering processes. Chromium is particularly vulnerable towards detrital contamination, requiring an Al-based correction of analyzed mean $\mathrm{Cr}$ concentrations and $\delta^{53} \mathrm{Cr}$ values. These corrected authigenic $\mathrm{Cr}$ values lower mean $\mathrm{Cr}$ concentrations and slightly elevate mean $\delta^{53} \mathrm{Cr}$ values. Not all $\mathrm{Cr}$ signals from the studied samples could be corrected due to high shares of detrital components, and a cut-off for the studied cap dolostones of the Doushantuo Formation has been applied at $40 \%$ detrital $\mathrm{Cr}$. Two samples in the deep water and one sample in the shallow marine cap dolostone section yield slightly positively fractionated $\delta^{53} \mathrm{Cr}$ signals, particularly when corrected for detrital 
input. These signals are in the range of previously reported $\delta^{53} \mathrm{Cr}$ values for Neoproterozoic carbonates and potentially reflect coeval seawater $\mathrm{Cr}$ signals. In the deep water cap dolostone section, a sample with a positively fractionated $\delta^{53} \mathrm{Cr}$ signal is also characterized by a high $\mathrm{Sr}$ concentration and an Ediacaran seawater-like ${ }^{87} \mathrm{Sr} /{ }^{86} \mathrm{Sr}$ value. The successfully corrected $\mathrm{Cr}$ data reveal positively fractionated $\mathrm{Cr}$ signals and indicate that these cap dolostones were possibly deposited in an oxygenated water column. We propose an Ediacaran marine carbonate $\mathrm{Cr}$ concentration of $>3 \mu \mathrm{g} \mathrm{g} \mathrm{g}^{-1}$ and chromium isotopic composition $\left(\delta^{53} \mathrm{Cr}\right)$ of $>0.0 \%$, based on results of few presumably pristine cap dolostones of the Doushantuo Formation, South China. An oxygenated water column is also supported by a pronounced negative Ce anomaly in the shallow marine cap dolostone section. The variability of the $\mathrm{Cr}$ isotope composition of the studied cap dolostones potentially indicates a signal of oxidative weathering balanced against variations in detrital contamination and/or against temporal or spatial fluctuations in hydrothermal fluid alteration. A post-depositional remobilization of positively fractionated $\mathrm{Cr}$, our preferred scenario to explain the $\mathrm{Cr}$ isotope data, is supported by a correlated loss of $\mathrm{Sr}$ and concurrent decrease in $\delta^{53} \mathrm{Cr}$ values. Decreasing $\delta^{53} \mathrm{Cr}$ values further correlate with increasingly light $\delta^{18} \mathrm{O}_{\text {carb }}$ signals, which would indicate meteoric fluid/rock interaction and diagenetic alteration by continental basin fluids. The $\mathrm{Cr}$ isotopic composition of Ediacaran cap dolostones potentially provide us with unique information about past climate variations related to Neoproterozoic ocean oxygenation and weathering regimes following the Marinoan glaciation, but need careful assessment with respect to the influence of detrital contamination and diagenetic alteration.

\section{Acknowledgements}

ASR thanks T. Leeper for TIMS maintenance, T. Larsen for keeping the $\mathrm{Cr}$ laboratories in perfect shape and M. Heckscher for continued access to KUnet. Financial support for ASR's PhD project, number 31512, was through the Danish Agency for Science, Technology and Innovation and the Nordic Center for Earth Evolution (NordCEE) was funded by the Danish National Research Foundation (DNRF; fund number DNRF53). SVH's PhD project was funded by the DFG Research Group FOR 736 subproject Be 583 1820/4-2. QG was funded by 973 Program (Nr. 2013CB835004) and the National Natural Science Foundation of China (NSFC Nos. 41173008 and 41473018). Furthermore, we would like to thank the Editor-in-Chief, Michael E. Böttcher, and two anonymous reviewers for their efforts and constructive comments that improved our initial manuscript.

\section{References}

Ader, M., Macouin, M., Trindade, R.I.F., Hadrien, M.-H., Yang, Z., Sun, Z., Besse, J., 2009. A multilayered water column in the Ediacaran Yangtze platform? Insights from carbonate and organic matter paired $\delta^{13} \mathrm{C}$. Earth Planet. Sci. Lett. 288 (1-2), 213-227. http:/ dx.doi.org/10.1016/j.epsl.2009.09.024.

Anbar, A.D., Duan, Y., Lyons, T.W., Arnold, G.L., Kendall, B., Creaser, R.A., Kaufman, A.J., Gordon, G.W., Scott, C., Garvin, J., Buick, R., 2007. A whiff of oxygen before the great oxidation event? Science 317, 1903-1906.

Asael, D., Tissot, F.L.H., Reinhard, C.T., Rouxel, O., Dauphas, N., Lyons, T.W., Ponzevera, E. Liorzou, C., Chéron, S., 2013. Coupled molybdenum, iron and uranium stable isotopes as oceanic paleoredox proxies during the Paleoproterozoic Shunga Event. Chem. Geol. 362, 193-210.

Ball, J.W., Nordstrom, D.K., 1998. Critical evaluation and selection of standard state thermodynamic properties for chromium metal and its aqueous ions, hydrolysis species, oxides, and hydroxides. J. Chem. Eng. Data 43 (6), 895-918.

Banner, J.L., Hanson, G.N., 1990. Calculation of simultaneous isotopic and trace element variations during water-rock interaction with applications to carbonate diagenesis. Geochim. Cosmochim. Acta 54, 3123-3137.

Basu, A., Johnson, T.M., Sanford, R.A., 2014. Cr isotope fractionation factors for $\mathrm{Cr}(\mathrm{VI})$ reduction by metabolically diverse group of bacteria. Geochim. Cosmochim. Acta 142, 349-361.

Bau, M., Dulski, P., 1994. Evolution of the yttrium-holmium systematics of seawater through time. Mineral. Mag. 85A, 61-62.

Bekker, A., Holland, H.D., Wang, P.-L., Rumble III, D., Stein, H.J., Hannah, J.L., Coetzee, L.L. Beukes, N.J., 2004. Dating the rise of atmospheric oxygen. Nature 427, 117-120.
Berger, A., Frei, R., 2014. The fate of chromium during tropical weathering: a laterite profile from Central Madagascar. Geoderma 213, 521-532.

Bonnand, P., James, R.H., Parkinson, I.J., Connelly, D.P., Fairchild, I.J., 2013. The chromium isotopic composition of seawater and marine carbonates. Earth Planet. Sci. Lett. 382, 10-20.

Bonnand, P., Parkinson, I.J., James, R.H., Karjalainen, A.-M., Fehr, M.A., 2011. Accurate and precise determination of stable $\mathrm{Cr}$ isotope compositions in carbonates by double spike MC-ICP-MS. J. Anal. At. Spectrom. 26, 528-535.

Brand, U., Veizer, J., 1980. Chemical diagenesis of a multicomponent carbonate system-1: trace elements. J. Sediment. Petrol. 50, 1-18

Brand, U., Veizer, J., 1981. Chemical diagenesis of a multicomponent carbonate system-2: stable isotopes. J. Sediment. Res. 51 (3), 987-997.

Cădkóva, E., Chrastný, V., 2015. Isotope evidence of hexavalent chromium stability in ground water samples. Chemosphere 138, 74-80.

Canfield, D.E., 1998. A new model for Proterozoic ocean chemistry. Nature 396, 450-453.

Canfield, D.E., Poulton, S.W., Knoll, A.H., Narbonne, G.M., Ross, G., Goldberg, T., Strauss, H., 2008. Ferruginous conditions dominated later Neoproterozoic deep water chemistry. Science 321, 949-952.

Chester, R., Murphy, K.J.T., 1990. Metals in the marine atmosphere. In: Furness, R., Rainbow, P. (Eds.), Heavy Metals in the Marine Environment. CRC Press, Boca Raton, FL, pp. 27-49.

Condie, K., Wronkiewicz, D., 1990. The $\mathrm{Cr} / \mathrm{Th}$ ratio in Precambrian pelites from the Kaapvaal Craton as an index of craton evolution. Earth Planet. Sci. Lett. 97, 256-267.

Condon, D., Zhu, M., Bowring, S., Wang, W., Yang, A., Jin, Y., 2005. U-Pb ages from the Neoproterozoic Doushantuo Formation, China. Science 308 (5718), 95-98. http:// dx.doi.org/10.1126/science.1107765.

Connelly, D.P., Statham, P.J., Knap, A.H., 2006. Seasonal changes in speciation of dissolved chromium in the surface Sargasso Sea. Deep-Sea Res. I 53, 1975-1988. http://dx.doi. org/10.1016/j.dsr.2006.09.005.

Crowe, S.A., Døssing, L.N., Beukes, N.J., Bau, M., Kruger, S.J., Frei, R., Canfield, D.E., 2013. Atmospheric oxygenation three billion years ago. Nature 501, 535-538.

Crowe, S.A., Døssing, L.N., MacLean, L.C., Mucci, A., Beukes, N.J., Fowle, D.A., Nomosatryo, S., Frei, R, Canfield, D.E., 2016. Oxidative weathering fractionates chromium isotopes. Earth Planet. Sci. Lett. (submitted for publication).

Dixon, S.K., Peacock, C.L., Parkinson, I.J., Fehr, M.A., James, R.H., 2013. A combined isotopic and XAS study of $\mathrm{Cr}$ incorporation into marine carbonates: towards verifying $\mathrm{Cr}$ isotopes as a palaeoredox proxy. Mineral. Mag. 77, 1926.

Døssing, L.N., Dideriksen, K., Stipp, S.L.S., Frei, R., 2011. Reduction of hexavalent chromium by ferrous iron: a process of chromium isotope fractionation and its relevance to natural environments. Chem. Geol. 285, 157-166.

Eary, L.E., Rai, D., 1987. Kinetics of chromium(III) oxidation to chromium(VI) by reaction with manganese dioxide. Environ. Sci. Technol. 21, 1187-1193.

Elderfield, H., Schultz, A., 1996. Mid-ocean ridge hydrothermal fluxes and the chemical composition of the ocean. Annu. Rev. Earth Planet. Sci. 24, 191-224.

Ellis, A.S., Johnson, T.M., Bullen, T., 2004. Using chromium stable isotope ratios to quantify $\mathrm{Cr}(\mathrm{VI})$ reduction: lack of sorption effects. Environ. Sci. Technol. 38, 3604-3607.

Ellis, A.S., Johnson, T.M., Bullen, T.D., 2002. Chromium isotopes and the fate of hexavalent chromium in the environment. Science 295, 2060-2062.

Eroglu, S., Schoenberg, R., Wille, M., Beukes, N., Taubald, H., 2015. Geochemical stratigraphy, sedimentology, and Mo isotope systematics of the ca. 2.58-2.50 Ga-old Transvaal Supergroup carbonate platform, South Africa. Precambrian Res. 266, 27-46.

Fairchild, I.J., Kennedy, M.J., 2007. Neoproterozoic glaciation in the Earth System. J. Geol. Soc. Lond. 164, 895-921

Farkaš, J., Chrastný, V., Novák, M., Čadkova, E., Pašava, J., Chakrabarti, R., Jacobsen, S.B., Ackerman, L. Bullen, T.D., 2013. Chromium isotope variations $\left(\delta^{53}{ }^{52} \mathrm{Cr}\right)$ in mantlederived sources and their weathering products: Implications for environmental studies and the evolution of $\delta^{53}{ }^{52} \mathrm{Cr}$ in the Earth's mantle over geologic time. Geochim. Cosmochim. Acta 123, 74-92.

Fendorf, S.E., Zasoski, R.J., 1992. Chromium(III) oxidation by $\delta-\mathrm{MnO}_{2}$. 1 . Characterization. Environ. Sci. Technol. 26, 79-85

Font, E., Nédélec, A., Trindade, R.I.F., Moreau, C., 2010. Fast or slow melting of the Marinoan snowball Earth? The cap dolostone record. Palaeogeogr. Palaeoclimatol. Palaeoecol. 295 (1-2), 215-225. http://dx.doi.org/10.1016/j.palaeo.2010.05.039.

Frei, R., Gaucher, C., Døssing, L.N., Sial, A.N., 2011. Chromium isotopes in carbonates - a tracer for climate change and for reconstructing the redox state of ancient seawater. Earth Planet. Sci. Lett. 312, 114-125.

Frei, R., Gaucher, C., Poulton, S.W., Canfield, D.E., 2009. Fluctuations in Precambrian atmospheric oxygenation recorded by chromium isotopes. Nature 461, 250-254.

Frei, R., Gaucher, C., Stolper, D., Canfield, D.E., 2013. Fluctuations in late Neoproterozoic atmospheric oxidation - $\mathrm{Cr}$ isotope chemostratigraphy and iron speciation of the late Ediacaran lower Arroyo del Soldado Group (Uruguay). Gondwana Res. 23, 797-811.

Frei, R., Poiré, D., Frei, K.M., 2014. Weathering on land and transport of chromium to the ocean in a subtropical region (Misiones, NW Argentina): a chromium stable isotope perspective. Chem. Geol. 381, 110-124.

Frei, R., Polat, A., 2013. Chromium isotope fractionation during oxidative weathering implications from the study of a Paleoproterozoic (ca. $1.9 \mathrm{Ga}$ ) paleosol, Schreiber Beach, Ontario, Canada. Precambrian Res. 224, 434-453.

Freudenthal, T., Wagner, T., Wenzhöfer, F., Zabel, M., Wefer, G., 2001. Early diagenesis of organic matter from sediments of the eastern subtropical Atlantic: evidence from stable nitrogen and carbon isotopes. Geochim. Cosmochim. Acta 65 (11), 1795-1808

Garnier, J., Quantin, C., Guimaraes, E., Becquer, T., 2008. Can chromite weathering be a source of $\mathrm{Cr}$ in soils? Mineral. Mag. 72, 49-53.

Garnier, J., Quantin, C., Guimarães, E.M., Vantelon, D., Montargès-Pelletier, E., Becquer, T., 2013. Cr(VI) genesis and dynamics in Ferralsols developed from ultramafic rocks: the case of Niquelândia, Brazil. Geoderma 193-194, 256-264.

German, G.R., Holliday, B.P., Elderfield, H., 1991. Redox cycling of rare earth elements in the suboxic zone of the Black Sea. Geochim. Cosmochim. Acta 55, 3553-3558. 
Guo, Q., Strauss, H., Liu, C., Goldberg, T., Zhu, M., Pi, D., Heubeck, C., Vernhet, E., Yang, X., Fu, P., 2007. Carbon isotopic evolution of the terminal Neoproterozoic and early Cambrian: evidence from the Yangtze Platform, South China. Palaeogeogr. Palaeoclimatol. Palaeoecol. 254 (1-2), 140-157. http://dx.doi.org/10.1016/j.palaeo.2007.03.014.

Hayes, J.M., Wedeking, K.W., Kaplan, I.R., 1983. Precambrian organic geochemistry preservation of the record. In: Schopf, J.W. (Ed.), The Earth's Earliest Biosphere: Its Origin and Evolution Vol. 5. Princeton University Press, Princeton, N.J., pp. 93-134.

Hoffman, P., Kaufman, A., Halverson, G., Schrag, D., 1998. A Neoproterozoic Snowball Earth. Science 281, 1342-1346.

Hoffman, P.F., Schrag, D.P., 2002. The snowball Earth hypothesis: testing the limits of global change. Terra Nova 14, 129-155.

Hohl, S.V., Becker, H., Herzlieb, S., Guo, Q., 2015. Multiproxy constraints on alteration and primary compositions of Ediacaran deep water carbonate rocks, Yangtze Platform, South China. Geochim. Cosmochim. Acta 163, 262-278.

Hohl, S.V., Becker, H., Jiang, S.-Y., Guo, Q., 2016. Geochemistry of Ediacaran cap dolomites of the Yangtze platform, South China. J. Geol. Soc. Lond. (under review).

Holland, H.D., 2006. The oxygenation of the atmosphere and oceans. Philos. Trans. R. Soc. B 361, 903-915.

Hua, B., Deng, B., Thornton, E.C., Yang, J., Amonette, J.E., 2007. Incorporation of chromate into calcium carbonate structure during coprecipitation. Water Air Soil Pollut. 179, 381-390.

Huang, J., Chu, X., Jiang, G., Feng, L., Chang, H., 2011. Hydrothermal origin of elevated iron, manganese and redox-sensitive trace elements in the c. 635 Ma Doushantuo cap carbonate. J. Geol. Soc. Lond. 168, 805-815. http://dx.doi.org/10.1144/0016-76492010-132.

Imai, N., Terashima, S., Itoh, S., Ando, A., 1996. 1996 compilation of analytical data on nine GSJ geochemical reference samples. Geostand. Newslett. 20, 165-216.

Izbicki, J.A., Ball, J.W., Bullen, T.D., Sutley, S.J., 2008. Chromium, chromium isotopes and selected trace elements, western Mojave Desert, USA. Appl. Geochem. 23, 1325-1352.

Jacobsen, S.B., Kaufman, A.J., 1999. The Sr, C and O isotopic evolution of Neoproterozoic seawater. Chem. Geol. 161, 37-57.

Jiang, G., Kaufman, A.J., Christie-Blick, N., Zhang, S., Wu, H., 2007. Carbon isotope variability across the Ediacaran Yangtze platform in South China: implications for a large surface-to-deep ocean $\delta^{13} \mathrm{C}$ gradient. Earth Planet. Sci. Lett. 261 (1-2), 303-320. http://dx.doi.org/10.1016/j.epsl.2007.07.009.

Jiang, G., Kennedy, M.J., Christie-Blick, N., 2003. Stable isotopic evidence for methane seeps in Neoproterozoic postglacial cap carbonates. Nature 426, 822-826.

Jiang, G., Shi, X., Zhang, S., Wang, Y., Xiao, S., 2011. Stratigraphy and paleogeography of the Ediacaran Doushantuo Formation (ca. 635-551 Ma) in South China. Gondwana Res. 19 (4), 831-849. http://dx.doi.org/10.1016/j.gr.2011.01.006.

Johnston, D.T., Poulton, S.W., Dehler, C., Porter, S., Husson, J., Canfield, D.E., Knoll, A.H. 2010. An emerging picture of Neoproterozoic ocean chemistry: insights from the Chuar Group, Grand Canyon, USA. Earth Planet. Sci. Lett. 290, 64-73.

Kasemann, S.A., Hawkesworth, C.J., Prave, A.R., Fallick, A.E., Pearson, P.N., 2005. Boron and calcium isotope composition in Neoproterozoic carbonate rocks from Namibia: evidence for extreme environmental change. Earth Planet. Sci. Lett. 231, 73-86.

Kelepertzis, E., Galanos, E., Mitsis, I., 2013. Origin, mineral speciation and geochemical baseline mapping of $\mathrm{Ni}$ and $\mathrm{Cr}$ in agricultural topsoils of Thiva Valley (central Greece). J. Geochem. Explor. 125, 56-68.

Kirschvink, J.L., 1992. Late Proterozoic low-latitude global glaciation: the Snowball Earth. Section 2.3. In: Schopf, J.W., Klein, C., Des Maris, D. (Eds.), The Proterozoic Biosphere: A Multidisciplinary Study. Cambridge University Press, pp. 51-52.

Kitchen, J.W., Johnson, T.M., Bullen, T.D., Zhu, J., Raddatz, A., 2012. Chromium isotope fractionation factors for reduction of $\mathrm{Cr}(\mathrm{VI})$ by aqueous $\mathrm{Fe}(\mathrm{II})$ and organic molecules. Geochim. Cosmochim. Acta 89, 190-201.

Knoll, A.H., 2011. The multiple origins of complex multicellularity. Annu. Rev. Earth Planet. Sci. 39, 217-239.

Konhauser, K.O., Lalonde, S.V., Planavsky, N.J., Pecoits, E., Lyons, T.W., Mojzsis, S.J., Rouxel, O.J., Barley, M.E., Rosiere, C., Fralick, P.W. Kump, LR., Bekker, A., 2011. Aerobic bacterial pyrite oxidation and acid rock drainage during the Great Oxidation Event. Nature 479, 369-373.

Lawrence, M.G., Kamber, B.S., 2006. The behaviour of the rare earth elements during estuarine mixing - revisited. Mar. Chem. 100 (1-2), 147-161. http://dx.doi.org/10 1016/j.marchem.2005.11.007.

Li, C., Love, G.D., Lyons, T.W., Fike, D.A., Sessions, A.L., Chu, X.L., 2010. A stratified redox model for the Ediacaran Ocean. Science 328, 80-83.

Lilli, M.A., Moraetis, D., Nikolaidis, N.P., Karatzas, G.P., Kalogerakis, N., 2015. Characterization and mobility of geogenic chromium in soils and riverbed sediments of Asopos basin. J. Hazard. Mater. 281, 12-19.

Ling, H.F., Chen, X., Li, D., Wang, D., Shields-Zhou, G.A., 2013. Cerium anomaly variations in Ediacaran-earliest Cambrian carbonates from the Yangtze Gorges area, South China: implications for oxygenation of coeval shallow seawater. Precambrian Res. 225, 110-127.

McLennan, S.M., 1989. Rare earth elements in sedimentary rocks: influence of provenance and sedimentary processes. Rev. Mineral. Geochem. Mineral. Rare Earth Elements 21, 169-200.

Morrison, J.M., Goldhaber, M.B., Mills, C.T., Breit, G.N., Hooper, R.L., Holloway, J.M., Diehl, S.F., Ranville, J.F., 2015. Weathering and transport of chromium and nickel from serpentinite in the Coast Range ophiolite to the Sacramento Valley, California, USA. Appl. Geochem. 61, 72-86.

Oze, C., Bird, D.K., Fendorf, S., 2007. Genesis of hexavalent chromium from natural sources in soil and groundwater. Proc. Natl. Acad. Sci. U. S. A. 104, 6544-6549.

Oze, C., Fendorf, S., Bird, D.K., Coleman, R.G., 2004. Chromium geochemistry of serpentine soils. Int. Geol. Rev. 46, 97-126.

Paulukat, C., Døssing, L.N., Mondal, S.K., Voegelin, A.R., Frei, R., 2015. Oxidative release of chromium from Archean ultramafic rocks, its transport and environmental impact $\mathrm{a} \mathrm{Cr}$ isotope perspective on the Sukinda valley ore district (Orissa, India). Appl. Geochem. 59, 125-138.

Paulukat, C., Gilleaudeau, G.J., Frei, R., The Cr-isotope signature of surface seawater - A global perspective. Mar. Chem. (in revision).
Pereira, N., Voegelin, A.R., Paulukat, C., Sial, A.N., Ferreira, V.P., Frei, R., 2015. Chromium isotope signatures in scleractinian corals from the Rocas Atoll, Tropical South Atlantic. Geobiology 14, 54-67. http://dx.doi.org/10.1111/gbi.12155.

Planavsky, N.J., Reinhard, C.T., Wang, X., Thomson, D., McGoldrick, P., Rainbird, R.H. Johnson, T., Fischer, W.W., Lyons, T.W., 2014. Low Mid-Proterozoic atmospheric oxygen levels and the delayed rise of animals. Science 346, 635-638.

Rai, D., Eary, L.E., Zachara, J.M., 1989. Environmental chemistry of chromium. Sci. Total Environ. 86, 15-23.

Rai, D., Sass, B.M., Moore, D.A., 1987. Chromium(III) hydrolysis constants and solubility of chromium(III) hydroxide. Inorg. Chem. 26, 345-349.

Reinhard, C.T., Planavsky, N.J., Wang, X., Fischer, W.W., Johnson, T.M., Lyons, T.W., 2014. The isotopic composition of authigenic chromium in anoxic marine sediments: a case study from the Cariaco Basin. Earth Planet. Sci. Lett. 407, 9-18.

Rodler, A., Sánchez-Pastor, N., Fernández-Díaz, L., Frei, R., 2015. Fractionation behavior of chromium isotopes during coprecipitation with calcium carbonate: implications for their use as paleoclimatic proxy. Geochim. Cosmochim. Acta 164, 221-235.

Rodler, A.S., Gaucher, C., Frei, R., Gaucher, C., Germs, G.J.B., Chromium isotope, REE and redox-sensitive trace element chemostratigraphy across the late Neoproterozoic Ghaub glaciation, Otavi Group, Namibia. Precambrian Res. (in revision).

Rouxel, O.J., Bekker, A., Edwards, K.J., 2005. Iron isotope constraints on the Archean and Paleoproterozoic ocean redox state. Science 307, 1088-1091.

Rudnicki, M.D., Elderfield, H., 1993. A chemical-model of the buoyant and neutrally buoyant plume above the TAG vent field, 26 degrees-N, Mid-Atlantic Ridge. Geochim. Cosmochim. Acta 57, 2939-2957.

Sahoo, S.K., Planavsky, N.J., Kendall, B., Wang, X., Shi, X., Scott, C., Anbar, A.D., Lyons, T.W., Jiang, G., 2012. Ocean oxygenation in the wake of the Marinoan glaciation. Nature 489, 546-549.

Sánchez-Pastor, N., Gigler, A.M., Cruz, J.A., Park, S.-H., Jordan, G., Fernández-Díaz, L., 2011 Growth of calcium carbonate in the presence of $\mathrm{Cr}(\mathrm{VI})$. Cryst. Growth Des. 11, 3081-3089.

Sander, S., Koschinsky, A., 2000. Onboard-ship redox speciation of chromium in diffuse hydrothermal fluids from the North Fiji Basin. Mar. Chem. 71, 83-102.

Sander, S.G., Koschinsky, A., 2011. Metal flux from hydrothermal vents increased by organic complexation. Nat. Geosci. 4, 145-150. http://dx.doi.org/10.1038/NGEO1088

Scheiderich, K., Amini, M., Holmden, C., Francois, R., 2015. Global variability of chromium isotopes in seawater demonstrated by Pacific, Atlantic, and Arctic Ocean samples. Earth Planet. Sci. Lett. 423, 87-97.

Schoenberg, R., Zink, S., Staubwasser, M., von Blanckenburg, F., 2008. The stable Cr isotope inventory of solid Earth reservoirs determined by double spike MC-ICP-MS. Chem. Geol. 249, 294-306.

Shen, Y., Zhang, T., Hoffman, P.F., 2008. On the coevolution of Ediacaran Oceans and oxygen. Proc. Natl. Acad. Sci. U. S. A. 105, 7376-7381.

Sikora, E.R., Johnson, T.M., Bullen, T.D., 2008. Microbial mass-dependent fractionation of chromium isotopes. Geochim. Cosmochim. Acta 72, 3631-3641.

Tang, Y., Elzinga, E.J., Lee, Y.J., Reeder, R.J., 2007. Coprecipitation of chromate with calcite: batch experiments and X-ray absorption spectroscopy. Geochim. Cosmochim. Acta $71,1480-1493$.

Taylor, S.R., McLennan, S.M., 1985. The Continental Crust: Its Composition and Evolution. Blackwell Scientific Pub., Palo Alto, CA, p. 312.

Trinquier, A., Birck, J.-L., Allègre, C.J., 2008. High-precision analysis of chromium isotopes in terrestrial and meteorite samples by thermal ionization mass spectrometry. J. Anal. At. Spectrom. 23, 1557-1696

van Zuilen, M., Schoenberg, R., 2013. Cr isotopes in near surface chemical sediments. In: Melezhik, V.A. (Ed.), Reading the Archive of Earth's Oxygenation vol. 3. SpringerVerlag, Berlin Heidelberg.

Veizer, J., 1983. Chemical diagenesis of carbonates: theory application. In: Arthur, M.A., et al. (Eds.), Stable Isotopes in Sedimentary Geology. Tulsa: S E P M Short Course. Soc Econ. Palaeont. Mineral Vol. 10 (3-1-3-100).

Vernhet, E., Heubeck, C., Zhu, M.Y., Zhang, J.M., 2006. Large-scale slope instability at the southern margin of the Ediacaran Yangtze platform (Hunan province, centra China). Precambrian Res. 148 (1-2), 32-44. http://dx.doi.org/10.1016/j.precamres. 2006.03.009.

Vernhet, E., 2007. Paleobathymetric influence on the development of the late Ediacaran Yangtze platform (Hubei, Hunan, and Guizhou provinces, China). Sediment. Geol. 197 (1-2), 29-46.

Voegelin, A.R., Frei, R., Thibault, N., Ullmann, C.V., Korte, C., 2013. Diagenesis affects carbonate $\delta^{53} \mathrm{Cr}$ : evidence from the K-Pg boundary section at Stevns Klint (Denmark). Mineral. Mag. 77 (5), 2422.

Voegelin, A.R., Nägler, T.F., Samankassou, E., Villa, I.M., 2009. Molybdenum isotopic composition of modern and Carboniferous carbonates. Chem. Geol. 265, 488-498.

Wang, X., Planavsky, N.J., Reinhard, C.T., Zou, H., Ague, J.J., Wu, Y., Gill, B.C., Schwarzenbach, E.M., Peucker-Ehrenbrink, B., 2016. Chromium isotope fractionation during subduction-related metamorphism, black shale weathering, and hydrothermal alteration. Chem. Geol. 423, 19-33. http://dx.doi.org/10.1016/j.chemgeo.2016.01.003.

Xiao, S., Zhang, Y., Knoll, A.H., 1998. Three-dimensional preservation of algae and animal embryos in a Neoproterozoic phosphorite. Nature 391, 553-558. http://dx.doi.org/10 $1038 / 28101$.

Yücel, M., Gartman, A., Chan, C.S., Luther III, G.W., 2011. Hydrothermal vents as a kinetically stable source of iron-sulphide-bearing nanoparticles to the ocean. Nat. Geosci. 4, 367-371. http://dx.doi.org/10.1038/NGEO1148.

Zhu, M., Zhang, J., Yang, A., 2007. Integrated Ediacaran (Sinian) chronostratigraphy of South China. Palaeogeogr. Palaeoclimatol. Palaeoecol. 254 (1-2), 7-61. http://dx. doi.org/10.1016/j.palaeo.2007.03.025.

Zink, S., Schoenberg, R., Staubwasser, M., 2010. Isotopic fractionation and reaction kinetics between $\mathrm{Cr}(\mathrm{III})$ and $\mathrm{Cr}(\mathrm{VI})$ in aqueous media. Geochim. Cosmochim. Acta 74, 5729-5745. 